\title{
LA REGULACION DE LAS RELACIONES MERCANTILES INTERNACIONALES Y EL DESARROLLO DEL DERECHO DEL COMERCIO INTERNACIONAL
}

\author{
Javier San Juan Crucelaegui
}

\begin{abstract}
Sumario: I. La insuficiencia del sistema conflictual para la regulación de las relaciones mercantiles internacionales. II. Del renacimiento de la lex mercatoria a la configuración del Derecho del comercio internacional (new law merchant). 1. El renacimiento de la lex mercatoria. 2. La configuración del Derecho del comercio internacional. III. La heterogeneidad formal de las normas integradoras del Derecho del comercio internacional y la diversidad de sus orígenes. 1. La aportación de los operadores del comercio internacional (lex mercatoria). A) La costumbre y los usos de comercio. B) Las recopilaciones y codificaciones de usos y prácticas. C) Los usos y prácticas observados por las partes en sus relaciones. D) Los contratos tipo. 2. El arbitraje internacional y el desarrollo del Derecho del comercio internacional. A) La progresiva decantación de principios generales reguladores de la contratación mercantil internacional. B) El arbitraje internacional y la autonomía del Derecho del comercio internacional. 3. La contribución de los Estados y organizaciones internacionales. A) Los Tratados y Convenciones. B) Las leyes modelo. C) Los principios generales para la regulación de la contratación comercial internacional. D) Las guías jurídicas. IV. El contenido del Derecho del comercio internacional. 1. Los caracteres del Derecho del comercio internacional y las normas que lo integran. A) La uniformidad reguladora pretendida: la exclusión del sistema conflictual. B) El carácter privado de las normas que integran el Derecho del comercio internacional: la exclusión de las normas de Derecho público reguladoras del tráfico económico. 2. La sistematización del Derecho del comercio internacional. V. Derecho internacional privado y Derecho del comercio internacional.
\end{abstract}

Tras la Segunda Guerra Mundial, ha tenido lugar una expansión continua y exponencial del comercio internacional ${ }^{1}$. Tal realidad eco-

\footnotetext{
${ }^{1}$ La progresión y crecimiento del comercio internacional son, ciertamente, exponenciales o geométricos. Al respecto, se hace mención, en las últimas décadas, de las siguientes magnitudes: 129 millones de dólares EE.UU. en 1960; 312 millones en 1970; 2.036 en
} 
nómica internacional, unida al progreso sin precedentes de la ciencia y de las tecnologías, ha llevado a Schmitthoff ${ }^{2}$ a señalar que the world has become a smaller place. La masiva producción de toda índole y, más en particular, de bienes industriales requieren mercados más amplios y mejores y más amplios circuitos y redes de distribución. La población de los países en vías de desarrollo ya no acepta la pobreza y la falta de oportunidades como sus condiciones naturales de vida y demanda ayuda y asistencia de las naciones más ricas y desarrolladas.

En lógica correspondencia, tal intensificación del comercio internacional ha traído consigo una reacción normativa ante la necesidad de una nueva fundamentación de la regulación jurídica de las relaciones internacionales. Y así, en los últimos años, ha surgido un conjunto de normas de diversa índole, procedencia y formulación, al que se hace referencia mediante una serie de denominaciones carentes de uniformidad, que tiene por finalidad la regulación del comercio internacional y, de forma más concreta, de los aspectos de derecho privado de las relaciones mercantiles internacionales. Tal fenómeno jurídico es la consecuencia de una creciente interrelación económica universal, que coincide en el tiempo con la recesión de los exacerbados nacionalismos del presente siglo y del anterior; es igualmente consecuencia de la substitución paulatina de una sociedad internacional fundada en el concepto de Estado soberano por la derivada de un concepto más amplio del orden mundial cimentado en el reconocimiento de la mutua interdependencia humana ${ }^{3}$. El aludido conjunto de normas, de paulatina aparición, busca facilitar el desarrollo del comercio internacional y su objeto estriba en la construcción de una regulación específica, de derecho privado, para las relaciones mercantiles internacionales ${ }^{4}$.

1980; 3.485 millones en 1990. Cfr. Comisión de las Comunidades Europeas en su informe Uruguay Round, Bruselas, 1992, pág. 1.

2 Cfr. Schmitthoff, Commercial Law in a Changing Economic Climate, Londres, Sweet \& Maxwell, 2. ${ }^{a}$ edición, 1981, pág. 18.

3 La afirmación es, nuevamente, de SchміттноғF, «International Trade and Private International Law», en Vom Deutschen Recht Zum Europaischen Recht, (Festschift für Hans Dolle), vol. II, Tubinga, 1963, pág. 265. De ella se hace eco en la doctrina española, GoNDRA ROMERO, «La moderna "lex mercatoria” y la unificación del derecho del comercio internacional», en Rev. de Derecho Mercantil, 1973, I, pág. 8.

4 Tales normas son las integrantes del Derecho del comercio internacional. Las denominaciones utilizadas son extremadamente variadas, tales como «Derecho mercantil internacional», «Derecho comercial internacional», «Lex Mercatoria», «Derecho de la contratación internacional». En la doctrina anglosajona, las más asentadas parecen ser las de «New Law Merchant», aun cuando parece usarse indistintamente la de "Law of 


\section{La insuficiencia del sistema conflictual para la regulación de las relaciones mercantiles internacionales}

La regulación de las relaciones internacionales es materia confiada por los ordenamientos jurídicos internos al Derecho internacional privado, disciplina que ha venido tradicionalmente sirviéndose del sistema conflictual para el cumplimiento de tal misión, de forma substancialmente única. La exagerada concepción acerca de la soberanía estatal ha causado el efecto de que el sistema conflictual fuera el único método de solución de problemas de tráfico jurídico externo de que dispusiera la citada disciplina jurídica ${ }^{5}$. Aunque la mayoritaria doctrina internacionalista de derecho privado no parece respaldar en la actualidad tal concepción ${ }^{6}$, permanece vigente la impresión de la ecuación entre derecho internacional privado y sistema conflictual, por lo que cualquier desarrollo normativo en la regulación de las relaciones internacionales parecería quedar fuera del ámbito del derecho internacional privado, en particular, si se toma en consideración la substancial inadecuación del sistema conflictual para la regulación de las relaciones mercantiles internacionales. Por el contrario, no parece que pueda seguir manteniéndose la ecuación citada, siendo posibles concepciones mucho más amplias acerca del derecho internacional privado.

the International Trade». Asimismo, en la doctrina francesa, fue inicialmente propuesta por Loussouarn y Bredin, Droit du Commerce International, París, Sirey, 1969. En la doctrina española, parece igualmente disfrutar de mayor aceptación la de Derecho del Comercio Internacional; tal es el título de Fernández Rozas (editor) «Derecho del comercio internacional», Madrid, Eurolex, 1996. Siendo un convencionalismo, pues todas ellas podrían ser consideradas como perfectamente sinónimas, estas dos últimas citadas parecen ser consideradas como las denominaciones que toman mejor en consideración la heterogeneidad de las formas y de los orígenes de las normas que integran la disciplina, característica esencial de la misma que supone un problema adicional para su sistematización.

5 Cfr. Loussounarn y BRedin, «Droit du Commerce International», cit. págs. 8 y 9.

${ }^{6}$ Sobre la evolución de las concepciones acerca del Derecho internacional privado, vid. BATIFFOL, «Les tendences doctrinales actuelles en droit international privé», en $R e-$ cueil des Cours de l'Académie de Droit International, 1948-1, vol. 72, págs. 29-33. La revisión y la ampliación metodológicas del derecho internacional privado fueron planteadas por BATIFFOL en, entre otros escritos, «Le pluralismo des métodes en Droit international Privé», en Recueil des Cours de l'Académie de Droit International, 1973-II, vol. 139, págs. 79 y sigs. Ha recibido un amplísimo respaldo doctrinal, vid. VAN HECKE, «Principes et metodes de solution des conflicts de lois», en Recueil des Cours de l'Académie de Droit International, 1969-I, vol. 126, págs. 467-472; en relación a la doctrina española, por todos, vid. CARrillo SAlcedo, Derecho Internacional Privado, Madrid, Tecnos, 1983, 3. a ed., págs. 77 y sigs; PÉREZ VERA (Dir.) Derecho Internacional Privado, UNED, 1998, págs. 79 y sigs. 
La aptitud del sistema conflictual ha concitado toda suerte de críticas en cuanto método para la regulación de las relaciones internacionales y es usual, desde hace algún tiempo, hacer mención de la crisis del derecho internacional privado, propugnándose su substitución por un método substantivista directamente de aplicación al fondo de los problemas que afectan a las relaciones internacionales ${ }^{7}$.

Es tradicional el reproche de índole básica y general que se esgrime frente al sistema conflictual en cuanto método de solución de cuestiones internacionales, pues pretende la regulación de una relación internacional por recurso a la aplicación de un derecho interno. Ello pone de manifiesto una carencia estructural, tal como puso de relieve Francescakis $^{8}$, pues no toma en consideración lo que las relaciones internacionales puedan tener de peculiar o específico por lo que un derecho interno no les resulta de exacta adaptación. Sin embargo, ello es lo que sucede en materia de contratos internacionales y en la mayor parte de las relaciones mercantiles. En suma, no parece pueda haber una ley interna capaz de proporcionar una reglamentación satisfactoria para una compraventa internacional, la cual no es una compraventa interna en la que se registra la complicación derivada de la presencia de un elemento de extranjería, sino que se trata de un contrato original y específico que comporta estipulaciones propias y específicas, lo que suscita órdenes distintos de dificultad.

Desde la década de los años sesenta, e incluso desde fechas anteriores, el sistema conflictual, en cuanto único sistema existente hasta la

7 Acerca de la impugnación del sistema conflictual, vid. LouSSOUARN, «Cours général de Droit International Privé», en Recueil des Cours de l'Académie de Droit International, 1973-II, vol. 139, págs. 282 y sigs; en especial, KEGEL, «The Crisis of Conflict of Laws», en Recueil des Cours de l'Académie de Droit International, 1964-II, vol. 112, págs. 237-263. Posición radical fue la adoptada por STEINDORFF, Sachnormen im internationalen l'rivatrecht, Francfurt, 1958, citado por Kegel, en la pretensión de substitución de las normas conflictuales por normas substantivas; asimismo, VON OVERBOCK, «Les regles de droit international privé matériel», en De conflicto legum, homenaje a Kollewijn y Offerhans, 1962, págs. 362-379. Acerca de las dificultades de las reglas de Derecho Internacional Privado material, afirma el citado autor (pág. 370) que se llega «a la conclusión de que únicamente mediante la substitución de los sistemas particulares de los Estados por reglas que emanen de un legislador internacional... puede llegarse a una solución verdaderamente satisfactoria»; la misma idea es defendida por SchмiтthofF, «International Trade and Private International Law» cit. pág. 265. Tal posición fue acogida en la doctrina española, si bien de manera no tan drástica, por Miaja De La Muela, «Las normas materiales de Derecho Internacional Privado», en Rev. Española de Derecho Internacional, 1963, vol. XVI, n. ${ }^{\circ}$, págs. 425 y sigs. En términos generales, vid. CARRILlo SAlCEDO, ob. cit. págs. 129 y sigs, especialmente, pág. 166.

8 Cfr. FranCESCAKIS, «Lois d'application immédiate et régles de conflict», en Rev. Critique de Droit International Privé, 1967, págs. 691 y sigs, especialmente pág. 736. 
fecha para la regulación de la problemática puesta de manifiesto por las relaciones internacionales, ha venido siendo considerado por la doctrina como inadecuado para la consecución de tal finalidad en razón de su intrínseca complejidad y como consecuencia de la incertidumbre generada por su característica actuación a posteriori, es decir, una vez surgida la diferencia entre las partes, de modo que éstas carecen de pauta jurídica en el momento de la asunción de sus respectivas obligaciones y derechos, pudiendo quedar tal catálogo de derechos y obligaciones alterado respecto del inicialmente previsto o pretendido mediante la acción de la norma de conflicto en su determinación de la aplicación de un sistema jurídico distinto al contemplado por las partes. A esta crítica no es ajena la carencia por parte del sistema conflictual de normas adecuadas a la regulación del tráfico mercantil internacional, lo que vendría a contraponerse con una cierta hipertrofia, más doctrinal que legislativa, apreciada por Carrillo Salcedo ${ }^{9}$, y presente en otros campos de las actividades internacionales de las personas privadas.

Más en particular, es puesta en cuestión la aptitud del sistema conflictual para la regulación de las relaciones mercantiles internacionales. En tal orden de ideas, afirma Gondra Romero ${ }^{10}$ que sólo un desfasado sentimiento de soberanía nacional puede explicar el predominio de que todavía goza el clásico método del conflicto de leyes en la disciplina de las relaciones comerciales internacionales. La superación de la óptica tradicional del Derecho internacional privado, siempre más atento a la seguridad y certeza del derecho aplicable que a su justicia y adecuación intrínsecas, ha contribuido a poner de manifiesto la insuficiencia del sistema conflictual.

La insuficiencia de las fuentes internas se pone claramente de manifiesto cuando se trata de la regulación de relaciones mercantiles internacionales ${ }^{11}$, de donde se sigue la necesidad de una reglamentación internacional lo que, a su vez, implica una alteración de fuentes. En dicho campo obligacional, el sistema conflictual se resiente de sus carencias. Es obvio que el comercio requiere rapidez y seguridad, de las que se deriva la necesaria certidumbre. Por el contrario, el sistema conflictual, con su determinación a posteriori del ordenamiento jurídico en que se debe encuadrar una relación jurídica, que sin embargo ya se ha desarrollado, frecuentemente no está en condiciones de ofrecer el míni-

9 Vid. al respecto, CARRILlo SAlCEDO, Derecho Internacional Privado, cit. pág. 145.

10 Cfr. Gondra Romero, «La moderna "lex mercatoria" y la unificación del Derecho del Comercio Internacional», cit. pág. 7.

11 Cfr. Loussounan y Bredin, Droit du commerce international, cit. pág. 8. 
mo de certeza y de previsibilidad que debe caracterizar a la norma jurídica. Ello resulta de particular importancia en lo tocante a la regulación de las relaciones mercantiles internacionales, no ya sólo porque el comercio tolera especialmente mal la inseguridad y la incertidumbre, sino, además, porque constituye un orden de problemas al que resulta especialmente mal adaptado el sistema conflictual en el que éste genera dosis especiales de incertidumbre.

El sistema conflictual es un método de resolución y no de previsión, pues las normas que lo integran no establecen anticipadamente pautas orientadoras de la conducta de las partes en consonancia con los derechos y obligaciones que pretenden y asumen. Las normas de conflicto responden a un procedimiento indirecto de designación de la norma que resolverá el conflicto una vez que éste se ha planteado o resulta inevitable. Sin embargo, las necesidades del comercio internacional, incrementadas por el incesante crecimiento de los intercambios comerciales, se mostraron incompatibles con un sistema regulador fundamentado en la resolución del conflicto de leyes. Y ello, no sólo por la incertidumbre que el mismo genera, sino también por la carencia que implica de previas pautas de cumplimiento y satisfacción. La seguridad y la celeridad del tráfico mercantil son incompatibles con un sistema que no fija con antelación suficiente la norma rectora de las conductas de las partes. En tales circunstancias de desconocimiento de aspectos importantes de las obligaciones contraídas en el momento de su perfección, el contrato comercial internacional y el comercio internacional no han encontrado nunca un trasfondo favorable para su desenvolvimiento e incremento.

No se deriva de lo expuesto la inutilidad plena del sistema conflictual ${ }^{12}$ que, con frecuencia, deberá colaborar en alcanzar la plenitud de la regulación de una relación mercantil internacional pero, por sí solo, ofrece el riesgo de proporcionar únicamente règles de résignation al comercio internacional, realmente sólo toleradas ante la imposibilidad de la aceptación de un vacío jurídico.

12 Es la afirmación de LousSOUARN y BREDIN, Droit du commerce international, cit. pág. 9. En sentido similar, IllesCAS ORTIZ, «El Derecho Uniforme del Comercio Internacional y su sistemática», en Rev. de Derecho Mercantil, 1993, pág. 46; por su parte, FERNÁNDEZ ROZAS, «Consideraciones en torno a la relevancia del derecho uniforme en la regulación del tráfico privado externo», en Estudios jurídicos en homenaje al Prof. Aurelio Menéndez, Tomo IV, Madrid, Civitas, págs. 5.227 y sigs. ofrece una visión en la que se concede una importancia no tan relevante a las normas materiales y, por el contrario, incide en la relevancia de las normas conflictuales en general y, en particular, acerca de su importancia en lo relativo a la determinación de los criterios para su interpretación. 


\section{Del renacimiento de la lex mercatoria a la configuración del Derecho del comercio internacional (new law merchant)}

Es de señalar que, en los inicios de la década de los sesenta, cuando tuvieron lugar las primeras reuniones de juristas procedentes de países con diferentes estructuras económicas y diferentes grados de desarro$1 \mathrm{lo}^{13}$, se puso de manifiesto que las técnicas jurídicas para la ordenación del comercio internacional eran las mismas en cualquier lugar del mundo, con independencia de la orientación política, ideológica o económica de los países en cuestión. Fueren los países capitalistas o socialistas, altamente industrializados o subdesarrollados, sus comerciantes compran o venden mercancías bajo los términos comerciales CIF o bien FOB, el pago se hace mediante crédito documentario u otros instrumentos internacionalmente reglamentados, el transporte de los bienes se hace respaldado por los mismos documentos y con los seguros habitualmente utilizados en el transporte internacional. La apreciación de tal igualdad en los mecanismos jurídicos universalmente utilizados en la ordenación de las relaciones mercantiles internacionales, disociadora de los aspectos jurídicos del comercio internacional frente a las diferencias de orientación política, ha sido puesta de manifiesto por Goldstajn ${ }^{14}$ para quien,

«the law governing trade transactions is neither capitalist nor socialist; it is a means to an end, and therefore, the fact that the beneficiaries of such transactions are different in this or that country is no obstacle to the development of international trade. The law of international trade is basad on the general principies accepted in the entire world».

13 En especial, la reunión promovida por la International Association of Legal Science, que tuvo lugar en Londres en septiembre de 1962, y que dio logar a la publicación del volumen The sources of the law of international trade, Londres, edit. Schmitthoff, Stevens \& Sons, 1964. En dicho coloquio, las siguientes cuestiones generales fueron objeto de tratamiento: $1 .^{\circ}$ ) «The relationship between the law of international trade and municipal commercial law»; $2 .^{\circ}$ ) «Autonomous law of international trade: its possibilities and limitations»; $3 .^{\circ}$ ) «The limits of party autonomy (including the admissibility of conclicyavoidance devices, and the municipal conflict of laws rules for the ascertainment of the law governing international trade transactions)». De entre las diversas ponencias, aun siendo todas ellas del máximo interés, pueden ser destacadas las de Schmiтthoff, The Law of International Trade, Its Growth, Formulation and Operation, págs. 3-38; GoldsTAJN, International Conventions and Standard Contracts as Means of Escaping from the Application of Municipal Law, págs. 111 y sigs; asimismo, las ponencias de KoPELMANAS, International Conventions and Standard Contracts as Means of Escaping from the Application of Municipal Law, págs. 118-126; y MALINTOPPI, International conventions and standard contracts, págs. 142 y sigs.

14 Cfr. Goldstajn, «The New Law Merchant Reconsidered», en Law and International Trade (Festschrift for Clive M. Schmitthoff), Francfurt, 1973, págs. 171. 
La doctrina sustenta la idea de que un derecho substantivo se está desgajando del sistema conflictual ${ }^{15}$. En este sentido, afirma Schmitthoff ${ }^{16}$,

«The law of international trade is assuming a new character; it is stedding its national limitations and, by acquiescence of the national sovereigns and with their authority, is transforming itself into an autonomous legal system, with characteristics essentially similar in all parts of the world».

Según la concepción del citado autor, el derecho del comercio internacional se habría desarrollado en tres etapas. La primera de ellas fue el período de la medieval lex mercatoria, auténticamente internacional, formada por las prácticas y usos desarrollados por la comunidad internacional de mercaderes en Europa y que, con el transcurso del tiempo, alcanzó calidad consuetudinaria. La segunda la constituyó la incorporación de este derecho medieval a los sistemas jurídicos nacionales a lo largo de los siglos diecisiete a diecinueve, con lo que el derecho del comercio internacional perdió cualquier nota que lo pudiera caracterizar como un sistema internacional de derecho. El tercer período es la fase contemporánea que se inició tras la finalización de la Segunda Guerra Mundial, y que constituye un consciente y deliberado retorno hacia el espíritu internacional del derecho del comercio internacional. Las nuevas circunstancias demandan un derecho autónomo del comercio internacional, de forma que dicha regulación convierta en superflua la localización de una transacción en una jurisdicción nacional. Y, en tal sentido ${ }^{17}$, afirma:

«We are beginning to rediscover the international character of commercial law and the circle completes itself: the general trend of commercial law everywhere is to move from the restrictions of national law to a universal, international conception of the law of international trade».

El derecho del comercio internacional ostenta un peculiar carácter, uniforme transnacional, que es puesto de manifiesto por Goldstajn ${ }^{18}$,

15 Para una panorámica general acerca de las distintas posiciones doctrinales, vid. KEGEL, The crisis of conflict of laws, cit. págs. 237-262.

16 Cfr. Schmitthoff, The Law of International Trade, Its Growth, Formulation and Operation, cit. pág. 3.

17 Cfr. Schmitthoff, Commercial Law in a Changing Economic Climate; International Trade and Private International Law, cit. pág. 19.

18 Cfr. Goldstajn, The New Law Merchant Reconsidered, cit. pág. 174. 
«The reason for the universal similarity of the law of international trade is that this branch of law is based on three fundamental propositions: (i) the principie of the autonomy of the parties' will; (ii) that the contract must be faithfully performed (pacta sunt servanda); (iii) the use of arbitration».

\section{El renacimiento de la lex mercatoria}

Para un sector de la doctrina ${ }^{19}$, ha sido la iniciativa ordenadora de los particulare ${ }^{20}$ la que ha dado lugar a la configuración de un conjunto normativo de las relaciones mercantiles internacionales ${ }^{21}$, originado al margen de la potestad legisladora de los Estados, y denominado lex mercatoria ${ }^{22}$.

19 Como precedente, un tanto lejano, de esta dirección doctrinal, se debe hacer mención de un antiguo trabajo de KopelmANAS, «Custom as a means of the creation of international law», en British Yearbook of International Law, 1937, vol. XVIII, págs. 127-151.

20 Entre dichos autores, cabe hacer mención principal de SchMiтTHOFF, de entre cuyos numerosos escritos cabe destacar los ya citados: Commercial Law in a Changing Economic Climate; International Trade and Private International Law, y The Law of International Trade, Its Growth, Formulation and Operation. Junto a ellos, se deben mencionar las siguientes publicaciones: «The new sources of the law of international trade», en International Social Science Journal, vol. XV-2; «The unification of the law of international trade», en Gothenburg School of Economics and Business Administration Publication, 1964, págs. 5-28; «The unification or harmonisation of law by means of standard contracts and general condictions», en The International and Comparative Law Quaterly, 1968, vol. 17, págs. 561-570; «The unification of the law of international Trade», en The Journal of Business Law, 1968, págs. 105-119; «Nature and evolution of the transnational law of commercial transactions», en The Transnational Law of International Commercial Transactions, edit. Kluwer Law and Taxation Publishers, Deventer, 1982, págs. 19-31; «The codification of the law of international trade», en The Journal of Business Law, 1985, págs. 34-44. Muchos de los trabajos del citado autor se encuentran recopilados en el volumen Clive $M$. Schmitthoff's Select Essays on International Trade Law, edit. Chia-Jui Cheng, Martinus Nijhoff Publishers / Graham \& Trotman Ltd, Dordrecht, Boston, London, 1988.

${ }_{21}$ Con los planteamientos del citado autor coincide plenamente el jurista yugoslavo GoldSTAJN. Ello queda patente en «The New Law Merchant», en Journal of Business Law, 1961, pág. 12; «The New Law Merchant Reconsidered», en Law and International Trade, Festschrift for Clive M. Schmitthoff, Francfurt, 1973, págs. 171 y sigs; «International Conventions and Standard Contracts as Means of Escaping from the Application of Municipal Law», en The sources of the law of international trade, págs. $111 \mathrm{y}$ sigs; "Commercial usages as the source of the law of international trade», en Melanges Fragistas, Salónica, 1967, págs. 391 y sigs.; posiblemente resulte de especial interés, «Reflections on the Structure of the Modern Law of International Trade», en International Contracts and Conflicts of Laws, edit. Sarcevic, Graham \& Trotman / Martinus Nijhoff, London / Dordrecht / Boston, 1990, págs. 14-36.

22 En la doctrina francesa, comparte la misma línea doctrinal KAHN, La vente commerciale internationale, París, edit. Sirey, 1961; «Droit international économique, droit du 
La concepción de la lex mercatoria renacida, a partir de los diversos pronunciamientos doctrinales, puede ser sintetizada del modo siguiente:

1. ${ }^{\circ}$ ) La lex mercatoria se compone de reglas materiales consuetudinarias.

Sus normas se aplican a una relación en la que se aprecia un elemento de extranjería sin pasar por el filtro de las normas conflictuales. Tales normas son plenamente jurídicas y se diferencian de aquellos comportamientos a los que su simple repetición en un medio profesionalmente caracterizado y limitado nunca sería suficiente para conferirles la dignidad de la norma jurídica. Por el contrario, dado que los actores del comercio internacional deciden regular su conducta de acuerdo con unas normas que son diferentes de los derechos internos, tales normas elegidas en el ejercicio de la libertad contractual se diferencian por su origen y, frecuentemente también por su contenido, de aquellas pertenecientes a un ordenamiento interno al que las partes hubieran podido hacer referencia expresa o tácitamente.

Tales normas no son «individuales» (en el sentido kelseniano del término $)^{23}$ puesto que las partes, al referirse a ellas, no tienen la inten-

développement, "lex mercatoria": concept unique ou pluralisme des ordres juridiques?», en Le droit des relations économiques internationales, Etudes offertes a Berthold Goldman, París, Litec, págs. 97-124. En línea similar, aunque no plenamente coincidente, FouCHARD, L'arbitrage commercial international, París, Dalloz, 1965; «L'etat face aux usages du commerce international», en Travaux du Comité Francais de Droit International Privé, 1974, págs. 71-101; «Les usages, l'artitre et le juge», en Le droit des relations économiques internationales, Etudes offertes à Berthold Goldman, París, Litec, págs. 67-87. En particular, GOLDMAN, «Frontieres du droit et "lex mercatoria"», en Archives de philosophie du droit, 1964, págs. 177 y sigs.; «La "lex mercatoria" dans les contrats et l'arbitrage internationaúx: realité et perspectives», en Travaux du Comité Francais de Droit International Privé, 1979, págs. 221-270; el trabajo está asimismo publicado en Journal du droit international (Clunet), 1979, págs. 475 y sigs.; en especial, «Lex Mercatoria», en Forum Internationale, Kluwer, Lecture n. ${ }^{\circ} 6,1985$. La concepción del último autor integra y supera las concepciones de Kahn y de Fouchard. Por su parte, LAGARDE, «Approche critique de la "lex mercatoria"», en Le droit des relations économiques internationales, Etudes offertes à Berthold Goldman, París, Litec, págs. 125-150, se separa de la línea sostenida por los autores anteriormente citados. Decididamente en contra de tal construcción, KAssis, Théorie générales des usages du commerce, París, LGDJ, 1984, en especial págs. 271 y sigs.

23 Opinión contraria es la sostenida por GONDRA ROMERO, art. cit. pág. 26. Para el citado autor, se trata más bien de normas que operan preferentemente en el plano contractual de la autonomía dispositiva de las partes, es decir, de normas individuales ex contractu, según la Stufenbautheorie de Kelsen. Al respecto, las dudas expresadas por GoldMAN, Frontieres de droit... cit, págs. 188-189. Ello, sin embargo, no le impide afirmar su extraterritorialidad al apoyarlas en un principio supranacional y común, así como en el principio pacta sunt servanda. 
ción ni el sentimiento de crear lazos jurídicos singulares; por el contrario, experimentan, aun cuando confusamente, la necesidad de situar su contrato en el marco de unas normas generales y abstractas que creen poder encontrar en un ordenamiento profesional, en los usos, o en principios generales que sobrepasan las fronteras nacionales. Las cláusulas de los contratos tipificados y las codificaciones de usos se corresponden con la definición de la norma jurídica, formulada con precisión suficiente para que los interesados la puedan conocer antes de establecer su acuerdo.

Los usos del comercio internacional, reglas generales, materiales y anacionales, son normas de calidad consuetudinaria. La lex mercatoria es un derecho consuetudinario transnacional, un derecho espontáneo constituido por usos profesionalmente codificados, cláusulas contractuales y conjuntos de contratos que regulan de forma constante y original las relaciones jurídicas entre los participantes en las operaciones internacionales, por lo que cabe plantear la cuestión de si su repetición no los ha elevado progresivamente al rango de instituciones consuetudinarias.

La mención de una calidad consuetudinaria implica referencia a la opinio iuris sive necessitatis, o convicción acerca del carácter obligatorio de la norma. En la definición propuesta por Goldman ${ }^{24}$, la regla de derecho es una norma que gobierna efectivamente una colectividad, porque sus miembros tienen consciencia de que su transgresión implica entrar en conflicto con el bien (como si de una norma moral o ética se tratara) y con la organización, es decir, las estructuras y el funcionamiento de esa colectividad. Tal es el caso de quienes participan en el comercio internacional. Así, por ejemplo, el banco que confirma un crédito documentario según las Reglas y Usos Uniformes de la CCI no tiene la impresión de colocarse en una situación de puro hecho, al margen de lo jurídico. En la situación jurídica en que se entiende situado, sería erróneo pensar que el contrato-tipo o el uso codificado se le impone como consecuencia de su libre adhesión. Por el contrario, las partes de un contrato internacional tienen el sentimiento de la obligatoriedad de las prescripciones del medio profesional. Aparece en ellas la consciencia de una regla común del comercio internacional simplemente expresada en el adagio pacta sunt servanda.

2..$^{\circ}$ Las reglas consuetudinarias que forman la lex mercatoria se descomponen en usos y en principios.

En la lex mercatoria cabe distinguir entre usos y principios, ostentando ambos calidad consuetudinaria, según la exposición de

$24 \mathrm{Al}$ respecto, vid. Goldman, La lex mercatoria dans les contrats et l'arbitrage... cit. págs. 224-234; en especial, Lex Mercatoria, cit. pág. 11. 
Fouchard ${ }^{25}$. Los usos corporativos o de «derecho corporativo» son para el citado autor reglas, aun cuando afectadas por un cierto particularismo inevitable derivado de las características propias de cada una de las actividades comerciales internacionales. Los principios son reglas más generales por su contenido y más universales por su ámbito geográfico de aplicación. Dichos principios, que realmente proceden de los sistemas jurídicos internos, no fundamentan su autoridad en los sistemas internos sino en la conciencia existente en la sociedad internacional, por lo que resultan ser reglas consuetudinarias propias del derecho del comercio internacional.

3..$^{\circ}$ La lex mercatoria dimana de una dualidad de fuentes, compuesta por las reglas consuetudinarias de derecho espontáneo y las reglas creadas por la jurisprudencia arbitral.

La lex mercatoria, en cuanto conjunto de reglas de derecho, tiene como primera fuente las prácticas profesionalmente codificadas, las cláusulas contractuales, los tipos o conjuntos contractuales nuevos, creados de manera espontánea por los participantes en el comercio internacional, puesto que tales prácticas o cláusulas han adquirido el rango de instituciones consuetudinarias por repetición.

El contenido de la lex mercatoria surge parcialmente de las reglas creadas por los laudos arbitrales, por lo que éstos constituyen la segunda fuente de este derecho anacional. La jurisprudencia arbitral produce substancialmente principios que, aun siendo parciales y ambiguos, pueden ser considerados como integrantes de la lex mercatoria.

4..$^{\circ}$ La lex mercatoria es un sistema jurídico, aun cuando incompleto y carente de autonomía.

La evolución experimentada por la lex mercatoria, aun siendo insuficiente para apreciar el nacimiento de un sistema jurídico completo, permite una sistematización de la misma, a su vez incompleta, pero creciente y posible dado que se encuentra compuesta por reglas de derecho aún no emanadas de autoridad legisladora. Tal origen, sin embargo, no es indispensable para la apreciación de la juridicidad de una norma, como lo prueba la existencia de la costumbre. No ha lugar a sostener una concepción restrictiva de la autoridad. Por el contrario, el concepto de regla jurídica se encuentra ligado a la idea de institución jurídica, a la de organización, a la de estructuras y funcionamiento de la colectividad de los operadores del comercio internacional.

25 Cfr. Fouchard, L’arbitrage commercial... cit. pág. 407. 
Sin embargo, la lex mercatoria no es todavía un sistema completo, por lo que requiere de su combinación con un sistema estatal, pues no contempla todas las relaciones a que puede dar lugar el comercio internacional. Por otra parte, no proporciona soluciones a cuestiones que podrían derivarse de la validez del consentimiento o de la capacidad de las partes contratantes, sin que sea previsible la formación futura de normas relativas a tales cuestiones. Tal limitación de su campo de aplicación no impide que proporcione una regulación de las relaciones mercantiles internacionales y que regule, efectivamente, la gran mayoría de las cuestiones que pueden surgir a propósito de la interpretación y ejecución de los contratos internacionales.

\section{La configuración del Derecho del Comercio Internacional}

Desde la década de los años setenta, la contribución de los Estados a la formación del derecho del comercio internacional ha sido mucho más activa, dando cuerpo a diversas convenciones internacionales reguladoras de determinadas relaciones mercantiles internacionales. De la suma de la iniciativa de los particulares y de la contribución de los Estados nace un conjunto normativo confusamente denominado pues para ello se utilizan, casi indistintamente, las expresiones New Law Merchant, por oposición a la de lex mercatoria únicamente comprensiva de las normas emanadas de los particulares, y la de Derecho del Comercio Internacional, asimismo comprensiva del conjunto de normas reguladoras del comercio internacional con independencia del origen y naturaleza de las normas.

Este conjunto normativo regula operaciones comerciales y ha sido definido ${ }^{26}$ como the body of rales governing commercial relationships of a private law nature involving different countries.

La inclusión del término «comercio» pone de manifiesto el carácter empresarial y profesional que revisten las operaciones y contratos integrados en el campo de aplicación del derecho del comercio internacional ${ }^{27}$. Por su parte, la Ley Modelo de la UNCITRAL sobre el Arbitraje

26 Tal definición es la contenida en el Report of the UN Secretary-General on the Progressive Development of the Law of International Trade, en «UNCITRAL Yearbook», 1968-1970, vol. I, Nueva York, 1971, pág. 20.

27 Cfr. GoldSTAJn, «Reflections on the structure of the modern law on international Trade», en International contracts and conflict of lows, edit, Sarcevic, Graham \& Trotman / Martinas Nijhoff, Londres, Dordrech, Boston, págs. 14 a 36. Con frecuencia se incluyen en los textos de las convenciones acerca del derecho del comercio internacional disposiciones que rezan: «La presente Convención no se aplicará a las compraventas: a) de mercaderías compradas para uso personal, familiar o doméstico». Tal orientación abunda en el carácter 
Comercial Internacional establece con claridad que el término «comercial» incluye los contratos innominados o los contratos desconocidos para los ordenamientos jurídicos internos, ensanchando su significado para dar cabida a las transacciones que son producto de la moderna práctica internacional ${ }^{28}$.

Dicho conjunto normativo que integra el Derecho del comercio internacional es de carácter internacional por su origen y en atención a su campo de aplicación. En razón de su campo de aplicación, porque tiene por objetivo la disciplina del comercio internacional. De modo más preciso, siguiendo las pautas definitorias del carácter de internacionalidad de las operaciones de comercio internacional utilizadas en las convenciones internacionales reguladoras de determinadas relaciones mercantiles, es internacional el contrato que se celebra entre partes que tienen sus establecimientos en Estados diferentes ${ }^{29}$. Internacional es

empresarial y profesional con el que se connota el campo de aplicación de las normas internacionales: cuando se afirma que este conjunto de normas compone el Derecho uniforme del comercio internacional, está poniéndose de relieve el carácter empresarial de las transacciones disciplinadas, las cuales, por otra parte, no resultan ser exclusivamente comerciales en sentido propio. Son también transacciones en el campo de la prestación de servicios, de la transformación de la naturaleza y de la circulación de capitales. Por consiguiente, el calificativo comercial y el término comercio son empleados en sentido impropio o figurado y en su seno se comprenden otras transacciones internacionales que, además de suponer un intercambio, se producen con finalidad empresarial y profesional. Por su parte, ILLESCAS ORTIZ, art. cit. págs. 41 y sigs. expone que la referencia al comercio caracterizado como internacional es una referencia imprecisa, pues tanto en las denominaciones comparadas como en la española, cuando se incluye el comercio como uno de los dos grandes conceptos delimitadores del campo de aplicación de las normas analizadas, la palabra empleada queda corta. Se paga tributo a una tradición histórica en virtud de la cual, en España, se denomina Derecho mercantil a algo más amplio que la rama disciplinadora del intercambio de mercancías. Se trata de poner de manifiesto que bajo el término «comercio» tiene cabida un número muy variado de prestaciones de servicios, financieros y de transporte principalmente, así como muchos aspectos de la actividad industrial o transformadora.

28 Cfr. Report of the UN Secretary-General on the Progressive Development of the Law of International Trade cit. pág. 22, par. 20. GoldSTAJN, Reflections on the structure of the modern law on international Trade, cit. basándose en dicho documento, establece de manera más precisa las transacciones incluibles dentro del derecho del comercio internacional.

29 Es el criterio en el art. 1 de la Convención de las Naciones Unidas sobre los contratos de compraventa internacional de mercaderías, hecha en Viena, el 11 de abril de 1980. Vid. comentarios al respecto de DíEz PiCAZo (Dir) La compraventa internacional de mercaderías. Comentario de la Convención de Viena, Madrid, Civitas, 1998, págs. 45-49; asimismo, Audit, La vente commerciale de marchandises. Convention des Nations Unies du 11 avril 1980, París, LGDJ, 1990, págs. 32 y sigs. Igual criterio es aplicado en el art. 2 de la Convención de las Naciones Unidas sobre las garantías independientes y los créditos documentarlos stand-by. Al respecto, vid. STOUFFLET, «La Convention des Nations Unies sur les garanties independantes et les lettres de credit stand-by», en Rev. Droit Bancaire et de la Bourse, $1995, \mathrm{n}^{\circ}$ 50, págs. 132-142. 
asimismo el origen de las normas que integran el Derecho del comercio internacional pues, en buena medida, su nacimiento es fruto de la iniciativa de los Estados, por lo general tras los trabajos de preparación llevados a cabo por organizaciones internacionales interestatales, generalmente denominadas formulating agencies ${ }^{30}$. En otras ocasiones, las normas son consideradas como uso o costumbre del comercio internacional, habiendo sido generadas por la práctica reiterada de los operadores del comercio internacional y, consiguientemente, al margen del poder normativo internacional de los Estados nacionales.

\section{La heterogeneidad formal de las normas integradoras del Derecho del comercio internacional y la diversidad de sus orígenes}

Las normas que integran el contenido del Derecho del comercio internacional dimanan de orígenes o fuentes de producción de las mismas completamente diversos por lo que a su naturaleza y forma externa se

30 La expresión fue acuñada por Schmitthoff, en International Business Law: a New Law Merchant, cit. págs. 31 y sigs. Es la expresión que ha recibido una aceptación generalizada. Por su parte, Gondra Romero, art. cit. pág. 7, emplea la expresión de «organismos formuladores». En suma, los Estados suelen actuar siguiendo la pauta marcada por las organizaciones internacionales que llevan a cabo la preparación del proyecto de convención que posteriormente será firmado por los Estados en el ejercicio de su poder creador de normas de Derecho. En lo relativo al Derecho del comercio internacional, los organismos de carácter intergubernamental que llevan a cabo tales tareas preparatorias resultan ser la «Comisión de las Naciones Unidas para el Derecho mercantil internacional» (UNCITRAL) y el «Instituto Internacional para la Unificación del Derecho Privado» (UNIDROIT). A ellas añade Schмiтtнoff la «Conferencia de La Haya de Derecho Internacional Privado» y «The Council for Mutual Economic Assistance»(CMEA, Moscú). Acerca de la UNCITRAL, vid. Resolución 2205 (XXI) de la Asamblea General de las Naciones Unidas, de 17 de diciembre de 1966, por la que se creó aquélla, en «United Nations Comission on International Trade», en Yearbook, vol. XXI, 1990, United Nations, New York, 1992. Sobre el UNIDROIT, Institut International pour l'unification du Droit privé, UNIDROIT, Roma, 1992.

Cuando estos organismos formuladores son distintos de las organizaciones internacionales intergubernamentales, se les denomina habitualmente establishment económico y jurídico internacional, y su principal exponente es la Cámara de Comercio Internacional de París. Son otro tipo de formulating agencies ajenas a los Estados en su organización y funcionamiento, y ligadas a la sociedad de comerciantes, de las que la CCI constituye la más patente manifestación. La CCI, asociación de operadores y juristas relacionados con el tráfico internacional, tiene como mérito la formulación escrita y sucesivas revisiones de normas del derecho del comercio internacional, originariamente configuradas como usos o costumbres internacionales. A ella cabe añadir «The International Maritime Committee» (Amberes) y «The International Law association» (Londres). Al respecto, cfr. SchMitTHOFF, Nature and Evolution of the Transnational Law of Commercial Transactions, cit. págs. 239-241, donde aparece consolidada la citada expresión. 
refiere, por lo que, consecuentemente, son heterogéneas en sumo grado. Las disposiciones que integran el sistema no poseen igual origen, ni se manifiestan a través del mismo revestimiento o forma externa, lo que no impide que todas ellas formen parte del sistema del Derecho del comercio internacional.

En coherencia con la tradición mercantil nacida de la nacionalización de la medieval lex mercatoria, las fuentes del Derecho del comercio internacional no son únicas ni homogéneas ${ }^{31}$. Ello hace que su sistematización resulte más difícil y que el conjunto de normas que lo integran comporte un grado de asistematicidad. Aun siendo ello cierto, parece exagerado afirmar que la lex mercatoria désigne maladroitement un magma de pratiques diverses, lacunaires, parfois contradictoires ${ }^{32}$.

Las normas que integran el Derecho del comercio internacional son objeto de diversas formalizaciones y, por ello mismo, ostentan naturaleza jurídica distinta como consecuencia de la diversidad de su origen. En tal sentido, las fuentes propiamente dichas del Derecho del comercio internacional son más complejas de lo que resultan ser las fuentes en los ordenamientos nacionales.

Sin entrar a analizar el sistema de fuentes, procede analizar la lista de las formas que adoptan las diversas normas que integran el Derecho del comercio internacional ${ }^{33}$. Sin embargo, es preciso destacar la decisiva relevancia de la voluntad de las partes intervinientes en la relación comercial internacional en cuanto a la utilización de tales normas, pues

31 Vid. sobre la cuestión, RoвLot, Traité élémentaire de Droit Commercial, Tomo 1, 11. a edición, París, LGDJ, 1984, pág. 33. Esta diversidad de fuentes se ha reconocido desde que existen los derechos mercantiles nacionales. De la tradición es tributario el Derecho mercantil codificado de principios del siglo XIX, que no puede dejar de reconocer la pluralidad efectiva de fuentes. Para IllesCAS OrTiz, art. cit. pág. 53, ese dualismo se reproduce en relación al Derecho del comercio internacional. Acerca de la cuestión, vid. GoLDSTAJN, Reflections on the structure of the modern law of international trade, cit. págs. 15-16.

32 La afirmación es de RigauX, «Les situations juridiques individuelles dans un systeme de relativité générale», en Recueil des Cours de l'Academie de Droit International de La Haye, 1989, Tomo 213, vol. 1, págs. 9-408.

33 La enumeración que sigue está inspirada en dos trabajos de Schmiтthoff, «The unification or harmonisation of law by means of standard contracts and general conditions», cit. y «The law of international trade», cit., ambos en Select Essays cit., respectivamente págs. 188-205 y 219-230. Asimismo, se inspira en buena medida, aunque no completamente, en la clasificación hecha por GoodE, «Reflections on the harmonisation of commercial law», en Revue de Droit Uniforme - Uniform Law Revue, 1991, I, págs. 54 y sigs., pues el citado autor da cabida a normas de derecho comunitario europeo, que no forman parte, por regionales, del derecho del comercio internacional. Se ha tenido en cuenta, igualmente, la clasificación de GOLDSTAJN, Reflections on the structure of the modern law of international trade, cit. pág. 16. 
de aquella depende la aplicación o exclusión de las normas que se enumeran. Se está en presencia de un Derecho de fuente legal y consuetudinaria, pero igualmente estamos ante un Derecho acusadamente dispositivo o convencional, en cuanto acuerdo de someter la relación a reglas preexistentes no imperativas cuya aplicación al caso en cuestión dependerá de la declaración expresa de sometimiento efectuada por las partes interesadas.

\section{La aportación de los operadores del comercio internacional (lex mercatoria)}

Los sujetos de la actividad disciplinada, es decir, los operadores económicos, la societas mercatorum, participan en la elaboración del sistema uniforme analizado e intervienen decisivamente junto a los Estados en la formación de muchas de las normas que integran el Derecho del comercio internacional. Son normas consuetudinarias los usos de comercio observados en la plaza y en el sector comercial de que se trate deben su origen, conforme a la concepción tradicional en los sistemas del Derecho romano, a la reiteración efectiva con que determinadas soluciones empíricas se vienen ofreciendo a problemas constantes.

\section{A) La costumbre y los usos de comercio}

La norma jurídica consuetudinaria es producida por la sociedad civil, entendida en su versión internacional como sociedad universal de comerciantes, no por su organización política. Los participantes en el comercio internacional han creado con sus hábitos reiterados de conducta una serie de pautas que se convierten en socialmente exigibles si revisten la opinio iuris, en la concepción de los ordenamientos de inspiración romanista ${ }^{34}$, o si pueden ser calificadas, en la concepción del derecho británico, como «razonables, ciertas y notorias», de donde se deriva su general aceptación ${ }^{35}$. Mecanismos jurídicos internacionales sometidos en la actualidad a reglamentación escrita tuvieron su origen en la costumbre comercial, frecuentemente reconocida como tal por los

34 Vid. la exposición de Garrigues, Curso de Derecho Mercantil, Tomo 1, Madrid, 1976, pág. 121, el uso mercantil no es cosa distinta de la costumbre; BroseTA PONT, Manual de Derecho Mercantil, 3. a edic. Madrid, Tecnos, 1978, págs. 60-61.

$35 \mathrm{El}$ concepto de uso de comercio en derecho británico puede verse en Halsbury's Laws of England, 4. ${ }^{\text {a }}$ edic. vol. 12, pág. 445. Los requisitos generales del uso son: (a) must be universally observed, (b) definite and certain, (c) reasonable, (d) and must not offend against the intention of any legislative enactment. Los calificativos mencionados se encuentran en la sentencia del caso Devonald vs. Rosser \& Sons, 1906, 2KB, 728-743. 
tribunales británicos. Tal resulta ser el caso del contrato CIF en general, y el de dicha venta especial en particular, así como el del crédito documentario ${ }^{36}$.

Por su parte, señala Illescas Ortiz ${ }^{37}$ que el artículo 9, par. 2, de la Convención de Viena de 1980 sobre compraventa internacional de mercaderías establece el valor normativo de la costumbre internacional confiriéndole un rotundo valor. Conforme a este precepto, la calificación de una práctica como uso o costumbre del comercio internacional depende de dos caracteres principales, cuales son la amplitud de su conocimiento y la regularidad de su observancia en el tráfico de que se trate.

La noción de costumbre en el ámbito de la regulación de las relaciones internacionales ha estado generalmente rodeada de confusión y ha sido objeto de discrepancias doctrinales. Schmitthoff ${ }^{38}$ rechaza la aplicación al uso de comercio internacional del concepto tradicional de costumbre del derecho norteamericano y del derecho británico, según el cual la costumbre debe ser long established or ancient. Por el contrario, adopta el criterio del Uniform Commercial Code de los EEUU ${ }^{39}$,

36 Cfr. Schmitthoff, International Business Law: a New Law Merchant, cit., pág. 34, atribuye carácter consuetudinario a ambos e incluye citas de abundante jurisprudencia mercantil británica en apoyo de su afirmación.

$37 \mathrm{El}$ art. 9, par. 2, de la Convención de Viena de 1980 establece: «Salvo pacto en contrario, se considerará que las partes han hecho tácitamente aplicable al contrato o a su formación un uso del que tenían o debían haber tenido conociniento y que, en el comercio internacional, sea ampliamente conocido y regularmente observado por las partes en contratos del mismo tipo en el tráfico mercantil de que se trate». $1^{\circ} .^{\circ}$ ) Desde el punto de vista de nuestro derecho, puede sorprender el reconocimiento de una gran libertad de pacto contra usum. Sin embargo, ello encuentra su fundamento en el principio de la plena libertad contractual en el comercio internacional recogido en el art. 6 de la Convención. 2. ${ }^{\circ}$ ) Por otro lado, de acuerdo con lo dispuesto en el art. 9, par. 1, de la Convención, «las partes quedarán obligadas por cualquier uso en el que hayan convenido», lo que puede volver a causar sorpresa. Ello es la consecuencia de que ciertos organismos elaboran normas denominadas usos y prácticas, que aspiran a la creación de la opinio iuris, pero que requieren actualmente un pacto para resultar de aplicación a la relación, lo que viene exigido por la seguridad jurídica internacional ante las diferentes concepciones jurídicas en la materia. El concepto aludido proviene del Uniform Commercial Code de los EEUU. Al respecto, vid. ILlESCAS ORTIZ, art. cit., págs. 65-67. En especial, HonNOLD, Uniform Law for International Sales, Deventer, 2. ${ }^{\text {a }}$ ed. 1989, págs. 116 y sigs.

38 Cfr. Schmitthoff, «International Trade Usages», en Institute of International Business Law and Practice, 1987, Publicación CCI n. ${ }^{\circ}$ 440/4, pág. 53, cita y se fundamenta en FARNSWORTH, para quien el término «usage of trade» es relativamente nuevo, preferido por el Uniform Commercial Code frente al más tradicional y estrecho término de «custom», término éste, sin embargo, preferido por el derecho británico.

39 Uniform Commercial Code (EEUU), par. 1, 205-2: «A usage of trade is any practice or method of dealing having such regularity of observance in a place, vocation or trade as to justify an expectation that it will be observed with respect to the transaction in question». 
según el cual es uso de comercio toda práctica observada de una forma lo suficientemente regular como para que esté justificada la previsión de su observancia en la relación de que se trate. La costumbre internacional se fundamenta en la voluntad de las partes que la adoptan como régimen de aplicación a su relación. A continuación, el citado autor distingue la costumbre internacional del uso de comercio en función de su formulación por un organismo internacional, de manera que es costumbre internacional la que hubiera sido objeto de formulación y codificación, mientras que es uso (convencional) aquella práctica carente de tal formulación y codificación.

La mención de una calidad consuetudinaria implica inmediata referencia a la opinio iuris sive necessitatis, o convicción acerca del carácter obligatorio de la norma. En la definición propuesta por Gold$\operatorname{man}^{40}$, la regla de derecho es una norma que gobierna efectivamente una colectividad, porque sus miembros tienen consciencia de que su transgresión implica entrar en conflicto con el bien (como si de una norma moral o ética se tratara) y con la organización, es decir, las estructuras y el funcionamiento de esa colectividad. Tal es el caso de quienes participan en el comercio internacional. Así, por ejemplo, el banco que confirma un crédito documentario según las Reglas y Usos Uniformes de la CCI no tiene la impresión de colocarse en una situación de puro hecho, al margen de lo jurídico. En la situación jurídica en que se entiende situado, sería erróneo pensar que el contrato-tipo o el uso codificado se le impone como consecuencia de su libre adhesión. Por el contrario, las partes de un contrato internacional tienen el sentimiento de la obligatoriedad de las prescripciones del medio profesional. Aparece en ellas la consciencia de una regla común del comercio internacional simplemente expresada en el adagio pacta sunt servanda.

En nuestro sistema, el uso mercantil o la costumbre internacionales no son cosa distinta de las surgidas en el ámbito interno, tal como expone Broseta Pont ${ }^{41}$, por lo que deben cumplir con iguales requisitos y obedecer a los mismos límites. Expone Gondra Romero ${ }^{42}$ al respecto que el primero proviene de la subordinación a la ley y la consiguiente ineficacia jurídica de la costumbre contra legem. No se tolerará, además, su oposición a los principios generales que informan nuestro ordenamiento (racionalidad de la costumbre) De otra parte, sólo se reconocerá valor normativo a la costumbre local» (art. $2 \mathrm{Cco}$ ) o

40 Cfr. Goldman, Frontieres du droit... cit. págs. 180 y sigs.

41 Vid. Broseta Pont, Manual... cit. pág. 61.

42 Cfr. Gondra Romero, art. cit. pág. 26. 
a los usos de comercio observados generalmente en cada plaza, con lo que el uso o costumbre internacional sólo encontrará aplicación y vendrá reconocido en la medida en que se demuestre su vigencia local. Los cauces, pues, para la penetración de la costumbre internacional en nuestro ordenamiento, concluye el citado autor, son realmente estrechos.

Sin embargo, hay pronunciamientos en nuestra doctrina acerca de la costumbre que pueden permitir en nuestro ámbito jurídico la aceptación de las tesis sostenidas por los máximos exponentes de la doctrina europea en la materia, en particular, la concepción de Goldman. Los autores - expone Castán Tobeñas — ${ }^{43}$ discrepan mucho en orden a la significación de la opinio iuris sive necessitatis, requisito un tanto obscuro, que es concebido ya como convicción, ya como sentimiento, ya como voluntad, y que para unos consiste en la simple persuasión de que una cosa debe valer como Derecho, mientras que para otros implica la conciencia de aquello que se observa sea ya Derecho, es decir, norma obligatoria y vigente. Por nuestra parte, continúa el citado autor, entendemos que ni puede exigirse, para la validez del Derecho consuetudinario, la convicción jurídica (pues el reconocimiento de la norma por la colectividad puede fundarse en motivos distintos de esa convicción, tales como el temor a las consecuencias de la transgresión, la comodidad, la rutina, etc.), ni siquiera tampoco la rigurosa intención de crear Derecho, que no se produce casi nunca en la práctica. Basta, según la tesis de Ennecerus, con que se dé en la colectividad o en sus órganos una voluntad general de validez jurídica, es decir, una voluntad que sea general en la esfera en la cual deba regir la norma jurídica.

En tal línea, siguiendo la exposición de Illescas Ortiz ${ }^{44}$, diversos factores han alterado los modos de actuar de la sociedad de mercaderes a la hora de producir pautas de conducta, entre los que cabe mencionar la dificultad práctica de la prueba del uso o la costumbre ante los tribunales, la rapidez y seguridad de los medios de comunicación escrita y electrónica, así como el reconocimiento generalizado de la libertad de pacto y su generalizada tutela por los tribunales. Ello se traduce en que, en la actualidad, más que costumbres basadas en la reiteración de conductas, se produce la formulación de reglas uniformes en forma escrita, cuya vigencia puede fundamentarse tanto en la condición de usos de comercio cuanto en la incorporación expresa de las mismas a un pacto

43 Cfr. Castán Tobeñas, Derecho Civil Español, Común y Foral, Tomo I, vol. 1, Madrid, Reus, 1975, págs. 450-451.

44 Cfr. IllesCAS ORTIZ, art. cit., pág. 59. 
escrito. La creciente complejidad de las operaciones, el incesante crecimiento de las jurisdicciones ante las cuales la costumbre no escrita debe de esgrimirse y el número no menos creciente de sujetos sometidos al uso de comercio en cuestión son factores que han traído como consecuencia la necesidad de formular por escrito las mencionadas costumbres mercantiles ${ }^{45}$.

La CCI, en ocasiones, con su conducta formuladora de reglas mercantiles no estatales, impide la posible configuración de algunas de ellas como usos de comercio para hacerlas pasar a la condición de meras cláusulas convencionales, cuya fuerza de obligar radica en la libertad de pacto ejercitada por las partes y no en la satisfacción por aquéllas de las ya expresadas condiciones de ser reglas «razonables, ciertas y notorias».

Por otra parte, la intervención de los Estados en la recopilación de disposiciones uniformes de procedencia consuetudinaria no suele excluir una participación activa de los operadores y de sus organizaciones privadas en la elaboración de las reglas que tienen a los propios Estados como fuente de producción. Ello resulta así ser incluso en los casos en los que las normas en cuestión se formulan ex novo sin haber sido precedidas de una práctica internacional generalizada y determinante de la aparición de un USO de comercio. Operadores y organizaciones participan muy activamente en las tareas preparatorias de las formulating agencies o de las conferencias en las que se concretan las nuevas disposiciones. La calidad de observador de la que se benefician en tales foros las asociaciones de empresarios facilita en gran medida la participación de los operadores y de sus organizaciones privadas en las tareas preparatorias, prácticamente en plano de igualdad con los Estados ${ }^{46}$.

$45 \mathrm{Al}$ respecto, vid. GoodE, Reflections on the harmonisation of commercial law, cit., págs. 56 y sigs.

46 Al respecto. vid. UNIDROIT, Conference diplomatique pour l'adoption des projets de conventions d'UNIDROIT sur l'affacturage international et sur le credit-bail international, Roma, 1991, págs. 150-151. Se recogen entre la lista de participantes diez organizaciones distintas de los Estados participantes, entre las cuales unas son intergubernamentales (UNCTAD), otras resultan ser organizaciones internacionales no gubernamentales («Comité Marítimo Internacional»), y otras son asociaciones profesionales internacionales («World Leasing Council»). Lo mismo puede apreciarse en los asistentes a la conferencia de Viena, de 10 de marzo de 1980, para la preparación de la Convención de Viena sobre compraventa de mercancías, Conferencia de las Naciones Unidas sobre los contratos de compraventa internacional de mercaderías. Documentos oficiales, Nueva York, 1981, pág. 190. En ella participaron como observadores no políticos ocho organizaciones distintas de los Estados. 
B) Las recopilaciones y codificaciones de usos y prácticas

Estas recopilaciones y codificaciones representan una etapa distinta tanto de la costumbre o uso de comercio cuanto de las prácticas negociales. Se caracterizan por constituir la formulación escrita y ordenada de una serie de pautas de conducta a seguir por las partes en los contratos a los que se refieren las recopilaciones en cuestión que son sectoriales y no generales ${ }^{47}$. Las recopilaciones presentan la peculiaridad de integrar en su seno normas que realmente no existían antes de la preparación de la recopilación, al menos parcialmente. No sólo se recopilan efectivas pautas de conducta socialmente exigibles y ampliamente respetadas con anterioridad a dicha recopilación, sino que también se produce una formulación de normas ad hoc y ex novo ${ }^{48}$ a las que se atribuye la expresada condición de recopilación de usos, reglas o prácticas. En esta tesitura, el sometimiento de una relación contractual a la recopilación es consecuencia de un pacto de sumisión incluido por las partes en el contrato de que se trate. Así llegan a indicarlo expresamente algunas recopilaciones. Tal sucede en los citados Incoterms $^{49}$, en las Reglas y usos uniformes en materia de créditos documentarios (RUU) ${ }^{50}$, o en las Reglas uniformes relativas a las garantías a primer requerimiento ${ }^{51}$.

Las recopilaciones mencionadas no son condiciones generales de contratación. La sumisión a las mismas no depende de la incorporación de ellas al contrato en cuestión. Son normas formuladas de modo abstracto y general, cuya aplicación a cada caso concreto depende de la voluntad de las partes. El sometimiento a las mismas puede efectuarse de modo parcial, mediante la exclusión de ciertos aspectos de las Reglas.

47 Cfr. Schmitthoff, The unification of international trade law, cit., págs. 239 y sigs.

48 Así lo observa GondRA ROMERo, art. cit. págs. 29-30, quien otorga a dichas recopilaciones un carácter «constitutivo»; de dicha afirmación se hace eco ILLESCAS ORTIZ, art. cit. pág. 70.

49 Cfr. Introducción Incoterms 2000, Publicación CCI, n. ${ }^{\circ}$ 560: «Los comerciantes que deseen aplicar esta normativa han de especificar que sus contratos quedan sometidos a los Incoterms».

50 La sumisión de los créditos documentarios a las RUU se produce igualmente a través de una declaración expresa incorporada por su emisor en el propio crédito documentario. Así lo indica el inciso final del artículo I de las Reglas, las cuales igualmente contemplan la posibilidad de pactar la exclusión de la sumisión del crédito a las normas uniformes. «Las presentes Reglas y usos uniformes... son de aplicación... siempre que así se establezca en el texto del crédito. Obligan a todas las partes... a menos que expresamente se estipule lo contrario...». Cfr. Publicación CCI, n. ${ }^{\circ} 500$.

51 La aplicación de las Reglas a las garantías a primera demanda depende siempre de una específica declaración de voluntad de las partes involucradas en la relación de garantía que la carta documenta. Así se deduce del tenor del art. 1 de las Reglas Uniformes Relativas a las Garantías a Primer Requerimiento, abril 1992, Publicación CCI n. ${ }^{\circ} 458$. 


\section{C) Los usos y prácticas observados por las partes en sus relaciones}

Estos usos y prácticas tienen su origen en la conducta negocial que las propias partes han establecido a lo largo de contratos anteriormente pactados entre ellas ${ }^{52}$. Constituyen estos usos y prácticas precedentes negociales que las partes han establecido en relaciones contractuales anteriores. Dado que carecen de carácter general, normas de esta índole difícilmente pueden ser consideradas como fuente de derecho, pues son una manifestación de la voluntad individual o un precedente tácitamente aceptado para resultar de aplicación a la relación actual. Sin embargo, en el marco del derecho del comercio internacional, determinados textos atribuyen valor normativo a tales precedentes contractuales al objeto de colmar lagunas existentes en un posterior contrato, de lo que se deriva que estos usos y prácticas merezcan una cierta consideración como fuentes.

A ellos se refiere el artículo 9, par. 1 de la Convención de Viena de 1980, precepto que resulta especialmente expresivo, al establecer que: «Las partes quedarán obligadas por cualquier uso en que hayan convenido y por cualquier práctica que hayan establecido entre ellas». Por su parte, los Incoterms ${ }^{53}$ ponen de manifiesto que, siendo imposible en muchas relaciones comerciales internacionales fijar por adelantado las obligaciones de las partes, dado que unas y otras se pueden enfrentar con una complejidad muy superior a la que genera el cumplimiento de contratos internos, resulta necesario referirse a otros medios determinadores. Además de hacerlo a «las costumbres profesionales o locales», es necesario, igualmente, remitirse a los usos que las propias partes hayan establecido en tratos anteriores ${ }^{54}$.

Estos usos o prácticas establecidas por las partes en contratos anteriores son distintos de la costumbre mercantil entendida como plena fuente de Derecho. La redacción del párrafo 2 del art. 9 de la Convención de Viena anteriormente citado ${ }^{55}$ y su comparación con el párrafo 1

52 Cfr. Schmitthoff, International Trade Usages, cit., págs. 11 y sigs.

53 Incoterms (1990), Publicación CCI, n. ${ }^{\circ}$ 460. Igualmente Incoterms 2000, Publicación CCI, n. ${ }^{\circ} 560$.

54 Ibidem, Preámbulo. La alusión a estos usos y prácticas negociales efectuada por los Incoterms tiene un valor inferior a la realizada por la Convención de Viena: la diferente naturaleza jurídica de quien lleva a cabo la indicación de los usos y prácticas así lo determina. La reglamentación llevada a cabo por la CCI se hace a través de un texto que sólo adquiere vigencia mediante su expresa aceptación por las partes; por el contrario, la regulación contenida en el artículo 9, par. 1, de la Convención de Viena se hace en un texto de especial relevancia para el Derecho del comercio internacional.

$55 \mathrm{El}$ art. 9, par. 2, de la Convención de Viena de 1980 establece: «Salvo pacto en contrario, se considerará que las partes han hecho tácitamente aplicable al contrato o a su formación un uso del que tenían o debían haber tenido conocimiento y que, en el comercio in- 
del mismo precepto ponen de relieve que el legislador se está refiriendo a dos fuentes normativas diferenciadas con alcances diferentes. Sin embargo, ambas cesan ante la manifestación de voluntad en contra de una u otra efectuada por las partes.

\section{D) Los contratos tipo}

La tipificación de los contenidos contractuales constituye un elemento de uniformización del Derecho del comercio internacional. Para cada uno de los sectores económicos más relevantes de dicho comercio, los empresarios y sus asociaciones internacionales formulan condiciones generales aplicables a los contratos en los que más frecuentemente intervienen aquéllos como parte. Los empresarios asociados pueden obligarse a la utilización de dichos contratos tipificados en los contratos que celebren bien a modo de recomendación, bien a modo de compromiso corporativo, siendo asimismo posible la previsión de una sanción para el caso de incumplimiento de la obligación de su utilización ${ }^{56}$. Del mismo modo, organismos internacionales han producido en ocasiones condiciones generales para concretos sectores de actividad. Tal es el caso de la Comisión Económica para Europa de las Naciones Unidas, la cual ha redactado y logrado amplia difusión para algunas condiciones generales relativas a intercambios de bienes ${ }^{57}$.

Estos contratos-tipo o condiciones generales constituyen una parte del contrato en el que se incluirán, además, otras condiciones particula-

ternacional, sea ampliamente conocido y regularmente observado por las partes en contratos del mismo tipo en el tráfico mercantil de que se trate». Cfr. supra pág. 66.

$56 \mathrm{Al}$ respecto, SchMiтthoff, «The unification or harmonisation of law by means of standard contracts and general conditions», en Select Essays... cit., págs. 188-218; el citado autor, pág. 191, tras admitir que su número es demasiado amplio como para proceder a un listado de dichas asociaciones profesionales que ofrecen contratos tipificados, menciona a las de mayor relevancia, que resultan ser «The London Corn Trade Association», fundada en 1877, la «Association of Corn Merchants of Hamburg» (1868), la «Bremen Cotton Exchange» (1872), la «Silk Association of America» (1873) y la «International Wool Textile Organisation» (1928). En especial, vid. SchмiтTHOFF, Export Trade, The Law and Practice of International Trade, Londres, Sweet \& Maxwell, 7. a edición, 1980, págs. 447 y sigs; vid. asimismo el listado de GoldSTAJn, en Commercial Usages as the Source of the Law of International Trade cit., págs. 391 y sigs; por su parte, ILLESCAS ORTIZ, art. cit. pág. 74, hace mención de la «Baltic and International Maritime Conference» que ha publicado el Catálogo de pólizas y documentos BIMCO.

57 Acerca de la labor de la «Comisión Económica para Europa de las Naciones Unidas», vid. Schmitthoff, The unification of international trade, cit., pág. 241. La Comisión ha redactado condiciones generales relativas a los intercambios de bienes de consumo duradero, productos de consumo tales como frutas y legumbres, plantas industriales, máquina-herramienta, etc. 
res y disposiciones específicas. La libertad de pacto subyace en el funcionamiento de este elemento generador de uniformidad en el Derecho del comercio internacional, pues la voluntad de la empresa que ofrece las condiciones, así como la de su cliente que las acepta, son las determinantes de la incorporación de las aludidas condiciones o clausulados al contrato que celebran, de forma que, sin la voluntad de uno y otro, la incorporación de aquéllas no tiene lugar ${ }^{58}$.

La uniformidad que este mecanismo produce en la regulación del tráfico internacional es dogmáticamente débil ${ }^{59}$, pues de la misma forma que la voluntad individual es la determinante de su empleo, esa misma voluntad es la determinante de su exclusión. Sin negar su influencia efectiva y material, cabe señalar la debilidad dogmática de los clausulados y condiciones generales de la contratación internacional aplicables en los respectivos ramos y sectores ${ }^{60}$.

\section{El arbitraje internacional y el desarrollo del Derecho del comercio internacional}

El establecimiento y la actividad constante de los tribunales permanentes de arbitraje dedicados a la resolución de controversias relativas a contratos comerciales internacionales resulta de relevancia en relación al Derecho del comercio internacional. La Cámara de Comercio Internacional es la sede del más conocido de tales tribunales estables, aun cuando no la única. Estos centros permanentes de arbitraje son constituidos por empresarios, cámaras de comercio o árbitros profesionales, sin participación alguna de los Estados en los que radican dichas organizaciones permanentes o en los que se suscitan los conflictos que dirimen.

A) La progresiva decantación de principios generales reguladores de la contratación mercantil internacional

La forma principalmente utilizada para dirimir sus diferencias por los participantes en el comercio internacional, frente al recurso a la instancia jurisdiccional, es el recurso al arbitraje internacional no funda-

58 Cfr. Schmitthoff, The unification or harmonisation of law by means of standard contracts and general conditions, cit., pág. 192; el criterio es también sostenido por KoPELMANAS, International Conventions and Standard Contracts as Means of Escaping from the Application of Municipal Law, cit., págs. 122-124.

59 Cfr. Gondra Romero, art. cit., pág. 37.

$60 \mathrm{Al}$ respecto. vid. ILLESCAS ORTIZ, art. cit., pág. 74, quien sigue la opinión de GoNDRA ROMERO, cfr. nota anterior. 
mentado en un derecho interno. De ello puede derivarse el nacimiento de una jurisprudencia arbitral formada por aquellos principios jurídicos de índole general, inicialmente acuñados o formulados por los propios árbitros, y que alcanzarían su definitiva decantación en virtud de su constante aplicación por dichos árbitros internacionales. Surgen así los principios generales de la contratación mercantil internacional, o reglas básicas a las que aquélla se adecua, emanadas de la práctica y cuya aplicación por los tribunales arbitrales contribuiría a desarrollar e integrar el catálogo de las fuentes reguladoras de dichos contratos en ausencia de estipulación expresa de las partes y de uso mercantil aplicable. Ello permitiría la exclusión de cualquier remisión a un ordenamiento jurídico interno así como la aplicación de las normas de conflicto ante la apreciación de lagunas en el contenido del derecho del comercio internacional.

La concepción de la lex mercatoria como un díptico compuesto por usos y principios fue inicialmente formulada por Fouchard ${ }^{61}$, para quien los usos son de naturaleza corporativa, con frecuencia privativos de cada profesión o de cada rama del comercio internacional. De manera diferente, los principios son principios generales de derecho privado, suficiente y universalmente admitidos, de manera que pueden constituir el embrión de una especie de «derecho común de las naciones» ${ }^{62}$. Por su parte, Loussouarn y Boure ${ }^{63}$ afirman «que los árbitros internacionales tienen el poder de crear normas materiales, que existe actualmente una creciente tendencia a favor de su reconocimiento, y que la utilización de tal facultad de creación de normas materiales tiende a desarrollarse».

61 Cfr. Fouchard, L’Arbitrage commercial international, cit., págs. 401-402; GolDMAN, La lex mercatoria et les contrats... cit., pág. 487.

62 Acerca de tales principios generales de derecho compartidos por las naciones y por los ordenamientos jurídicos, vid. Jessup, Transnational Law, Yale University Press, 1956, págs. 1-13, en que el autor fue de los primeros en defender que el derecho transnacional regula sucesos que transcienden las fronteras nacionales, formando parte del derecho internacional público y del derecho internacional privado; asimismo, Lord Mc. NAIR, «The General Principles of Law Recognized by Civilized Nations», en British Yearbook of International Law, 1957, págs. 1-19; BANER, «Les traités et les regles de droit international privé matériel», en Rev. Critique de Droit International Privé, 1966, págs. 537-574; LEVEL, «Le contrat dit sans loi», en Travaux du Comité Francais de Droit International Privé, 1966, págs. 209-243; WENGLER, «Les principes généraux du droit en tant que loi du contrat», en Rev. Critique de Droit International Privé, 1982, págs. 467-501. Un estudio de amplio alcance de la cuestión en la actualidad puede verse en Osman, Les principes généraux de la «Lex Mercatoria», París, LGDJ, 1992.

63 Cfr. Loussounn y Bourel, Droit International Privé, París, Dalloz, 4. a edición, págs. 49 y sigs. 
Por su parte, Goldman ${ }^{64}$ sostiene que los principios de la lex mercatoria no deben ser asimilados ni a los principios de derecho internacional ni a los principios generales de derecho comunes a los sistemas nacionales. No es infrecuente que los contratos mercantiles internacionales contengan una cláusula arbitral en la que se expresa la ley que deberá ser utilizada por el árbitro. Con frecuencia, tal elección se hace por referencia a los «principios de derecho internacional» o a los «principios generales de derecho», expresiones cuya significación está lejos de ser pacífica.

Podría pensarse, en primer lugar, que constituyen una referencia al derecho internacional público, puesto que éste es el derecho internacional stricto sensu, y dado que el artículo 38 del Estatuto del Tribunal Internacional de Justicia los cita, como una de sus fuentes, junto a los tratados y a la costumbre internacional. Al respecto, observa Gold$\operatorname{man}^{65}$ que difícilmente cabe admitir que las empresas privadas piensen en hacer referencia precisa y limitativa al citado precepto, texto de derecho internacional público que no atrae la atención de las empresas privadas. En segundo lugar, si lo aludido por las citadas expresiones es el derecho internacional privado, internacional por su objeto pero no por su fuente, se habrá de concluir que lo aludido son los principios generales comunes a una mayoría de los diversos derechos internos, puesto que los contratantes, cuando se sirven de la expresión «principios», entienden hacer referencia a unas reglas materiales y no a unas normas conflictuales que no proporcionan directamente una solución a su diferencia. Por tanto, concluye el citado autor, las citadas referencias contractuales lo son a la lex mercatoria, pues «siendo una equivocación situar la fuente directa de los principios aludidos por el art. 38 en las codificaciones profesionales, las prácticas o los usos del comercio internacional, no es discutible que por su carácter consuetudinario, su campo de aplicación y su contenido, dichos principios (tal como han sido definidos por la jurisprudencia y por la doctrina, dado que el art. 38 los menciona globalmente, sin enumerarlos), se insertan en este derecho económico común que conforma, precisamente, la lex mercatoria, $y$ en verdad, la dominan» ${ }^{66}$.

En apoyo de su tesis, invoca Goldman ${ }^{67}$ el contenido de los principios generales de derecho clasificados por los publicistas ${ }^{68}$ en tres categorías.

64 Vid. Goldman La lex mercatoria dans les contrats... cit. («Clunet») pág. 487.

65 Cfr. Goldman, ibidem.

66 Cfr. Goldman, La lex mercatoria dans les contrats... cit. («Clunet») pág. 488.

67 Cfr. Goldman, La lex mercatoria dans les contrats... cit. («Clunet») pág. 489.

68 El citado autor se fundamenta en Rousseau, Droit International public, Tomo I, París, Sirey, págs. 379-389. 
1. a) La primera es la compuesta por las reglas de derecho relativas a las obligaciones contractuales o cuasi contractuales, y en ella se insertan principios relativos al nacimiento de las obligaciones (enriquecimiento sin causa, o gestión de negocios); principios relativos a su ejecución (pacta sunt servanda, o el interés moratorio); principios relativos al ejercicio de los derechos (abuso de derecho), al respeto a los derechos adquiridos, y a la extinción de las obligaciones (el controvertido principio de la prescripción liberatoria).

2. a) La segunda categoría contiene las reglas extraídas de las obligaciones delictuales o cuasi delictuales, que imponen la obligación de reparación del perjuicio causado así como el discutido principio de la medida de la reparación, es decir, si la reparación incluye el lucrum cessans.

3. $\left.{ }^{a}\right)$ La tercera categoría incluye las reglas procedimentales relativas a la cosa juzgada, el régimen de la prueba y el principio de interdicción del venire contra factum propium (estoppel). Y concluye que es claro que, al referirse a los «principios generales de derecho» o a los «principios de derecho internacional», las partes del contrato internacional entienden someterse, precisamente, a las reglas y principios contenidos en las diversas categorías aludidas. Por tanto, las partes, que entienden someterse a estos principios, los consideran como conformadores de un sistema jurídico propio, la lex mercatoria.

Por su parte, de forma más concisa, Schmitthoff ${ }^{69}$ expone que, al haber adquirido la lex mercatoria un carácter de sistema legal autónomo en los últimos años, es forzoso reconocer que ha dado lugar a la de-

${ }^{69}$ Cfr. Schmittoff, International trade usages... cit. pág. 47. El autor incluye una serie de sentencias dictadas por tribunales austríacos, italianos, británicos y franceses, en las que se ha aceptado que las partes y los árbitros se sometan o apliquen la lex mercatoria, en cuanto sistema legal autónomo, cuando se trata de determinar la ley de aplicación al contrato. Asimismo, el citado autor examina la relación entre arbitraje y creación de principios jurídicos en «Extrajudicial Dispute Settlement», en Forum internationale, Kluwer, Lecture n. ${ }^{\circ}$ 6, mayo 1985; en el mismo sentido se pronuncia LANDO, «The lex mercatoria in international commercial arbitration», en International and Comparative Law Quaterly, 1985, vol. 34, págs. 747 y sigs.; por su parte, LALIVE, en la conferencia pronunciada ante el ICCA, New York Conference, 1986, titulada Transnational (or truly international) Public Policy and International Arbitration, afirmó que «There is little doubt that a number of essential principles of the intenational law of arbitration have acquired the character, or the "dignity" of general principles of the law of international trade; arbitrators no longer hesitate to apply them as a common law (and the terminology they use appears of little relevance, e.g. a substantive private international law common to several States or common to both international law and the private international law the State, or lex mercatoria, etc.)». 
finición de determinadas reglas o principios de derecho, entre los que destaca:

«The first is the principle that merchants in their international dealings shall observe the demands of good faith. Secondly, the principle that contracts have to be performed unless there is a valid excuse for non-performance (pacta sunt servanda) is a clear rule of the lex mercatoria. Thirdly, the rules of interpretation ut res magis valeat quam pereat and contra preferentem fall into this category. Fourthly, the rule of venire contra factum propium (estoppel) has to be mentioned. Fiftly, there may be a principle of equilibrium of reciprocal undertakings».

Los principios generales de la contratación internacional supondrían, de este modo, una defensa de las relaciones internacionales frente a cualquier irrupción, aun residual, de los derechos internos ${ }^{70}$. Dichos principios constituirían una realidad normativa, emanación directa y autónoma de los contratos sometidos al Derecho del comercio internacional, y creación de la práctica universal. Asimismo, una vez fijados, definidos y establecidos, contribuirían a la autonomía del derecho del comercio internacional frente a los sistemas estatales. Estos principios, así concebidos, poseerían una considerable importancia dogmática y un decisivo papel en orden al aseguramiento de una aplicación autónoma del Derecho del comercio internacional.

Los principios generales de la contratación comercial internacional y sus funciones en la actualidad puede considerarse son ya una incipiente realidad, que dispone de un definido perfil tras la publicación por el UNIDROIT, en 1995, de los Principios sobre los Contratos Comerciales Internacionales, tras la ardua tarea de su identificación, recopilación y formulación escrita que ha permitido la fijación de las condiciones de su utilización por contratantes y árbitros, así como por los tribunales internos ${ }^{71}$.

B) El arbitraje internacional y la autonomía del Derecho del Comercio Internacional

Realmente, las diferentes y encontradas posiciones doctrinales acerca de la propia concepción de la lex mercatoria y del papel del arbitraje internacional en su configuración son la consecuencia de las dis-

70 Es la afirmación de GoldsTAJn, Commercial usages as the source of the law of international trade... cit. pág. 395; en el mismo sentido, ILLESCAS ORTIZ, art. cit. pág. 84.

71 UNIDROIT, Principios sobre los Contratos Comerciales Internacionales, Roma, 1995. 
crepancias en lo tocante a la aceptación de la pretendida autonomía del derecho del comercio internacional, la cual convertiría a éste en una disciplina jurídica ajena al poder normativo de los Estados ${ }^{72}$. Siempre se ha afirmado la autonomía de la lex mercatoria y del derecho del comercio internacional como rasgo esencial de una y de otro. Sin embargo, el significado y alcance de dicha autonomía no han sido precisados por los distintos pronunciamientos doctrinales, aun cuando puede entenderse como su cualidad para existir y desarrollarse al margen de los Estados, al amparo exclusivamente de la fuerza generadora desplegada por la sociedad civil y económica universal. La fundamentación de tal autonomía reposaría sobre dos consideraciones.

En primer lugar, la constante creación de normas por los operadores, organizaciones internacionales privadas o interestatales, y que constituyen el núcleo del derecho del comercio internacional. Esta actividad creadora podría decirse ha encontrado un punto de culminación en la redacción por el UNIDROIT de los Principios Generales antes mencionados.

Frente a tal actividad creadora, es necesario tomar en consideración, en lo tocante a la apreciación de la autonomía del derecho del comercio internacional, que los Estados son también creadores del Derecho del comercio internacional, en cuyo seno conviven normas de producción particular con normas de producción estatal. La realidad contemplada es el elemento de relevancia mayor en la definición y sistematización de una rama jurídica, frente a un criterio parcial constituido por la peculiaridad de las fuentes. No es el sistema de fuentes lo que caracteriza a una disciplina, sino la materia cuya regulación pretenden las normas producidas por sus creadores, fueren éstos los Estados o la societas mercatorum y sus agentes, o unos y otros conjuntamente ${ }^{73}$. Esta consideración acerca de las formas de producción del Derecho del comercio internacional, en la que participan los Estados y la societas mercatorum, hace que su autonomía

72 Son escasos los pronunciamientos de la doctrina española al respecto, y los que se han producido parecen ser hostiles a tal posibilidad. Señaladamente, vid. GONDRA RoMERO, art. cit. págs. 35-37; en particular, DE CASTRO Y BRAVo, «El arbitraje y la nueva "lex mercatoria”», en Anuario de Derecho Civil, 1979, fascículo IV, págs. 619-725.

73 Vid. Ia exposición de Goldman, Frontieres du droit... cit. págs. 180 y sigs. Por su parte, ILlESCAS ORTIZ, art. cit. pág. 80, afirma, asimismo, que es la realidad regulada lo que debe primar a efectos definitorios y sistematizadores, de acuerdo con la dogmática jurídica moderna preconiza. Dicho criterio se apoya, por lo que al Derecho español se refiere, en los artículos 1 del Código civil y 2 del Código de comercio, que dan testimonio de la validez del criterio definitorio material y de la invalidez del criterio del origen de las normas. 
sólo pueda afirmarse de modo relativo, pues tal dualidad no parece ser fundamento suficiente para la autonomía del Derecho del comercio internacional.

En segundo lugar, la autonomía se fundamentaría en la aplicación del indicado conjunto de reglas por los tribunales arbitrales a los que recurren los participantes en las relaciones mercantiles internacionales al objeto de excluir la intervención de los tribunales internos en la resolución de sus diferencias. En cuanto a esta segunda consideración, la aplicación directa de los usos por los árbitros al caso de que se trate encuentra un respaldo internacional. Las organizaciones internacionales vienen respaldando el poder normativo de los usos de comercio mediante instrumentos internacionales de diversa naturaleza. Asimismo, invitan a las partes de los contratos mercantiles internacionales a que reconozcan dicho poder normativo de los usos de comercio, y a que atribuyan a los árbitros facultades para que tomen en consideración los usos aplicables al caso. Adicionalmente, se recomienda a los Estados que procedan a su reconocimiento. Algunos instrumentos llegan, incluso, a imponer la vigencia del uso de comercio con independencia de voluntad manifestada al respecto ${ }^{74}$.

La relevancia del arbitraje como método de resolución de diferencias y su amplia difusión son obvias ${ }^{75}$. La autonomía arbitral se acentúa

74 Es lo dispuesto en el artículo 33, par. 3, del Reglamento de arbitraje de UNCITRAL Resolución 31/98 de la Asamblea General de Naciones Unidas, de 15 de diciembre de 1976, el cual, al pronunciarse sobre la ley aplicable, establece que «En todos los casos, el tribunal arbitral decidirá con arreglo a las estipulaciones del contrato y tendrá en cuenta los usos mercantiles aplicables al caso». Vid. al respecto, Reglamento de Arbitraje de CNUDMI, Naciones Unidas, Nueva York, 1977, S.77.V.6.

La misma fórmula es utilizada por el art. 24, par. 4, de la Ley Modelo de UNCITRAL sobre arbitraje comercial internacional, Resolución 40/72 de la Asamblea General de Naciones Unidas, 11 de diciembre de 1985, Doc. A/40/17, anexo I.

A su vez, los instrumentos citados ponen de manifiesto un contenido altamente similar a otras reglas contenidas en otros instrumentos internacionales relativos al reconocimiento y ejecución de laudos arbitrales internacionales, vgr. Convenio Europeo sobre arbitraje comercial internacional, de 21 de abril de 1961, BOE de 4 de octubre de 1975.

La generalización de la fórmula transcrita y su difusión directa o indirecta mediante la referencia al Reglamento de arbitraje de UNCITRAL, asociada a la capacidad para generar usos de diversa categoría de la sociedad internacional de comerciantes, hace que quepa apreciar la existencia de un fundamento de la autonomía del Derecho del comercio internacional, pues tales nuevos usos, que se aplican por los árbitros directa y espontáneamente y cuya utilización no puede ser objeto de excepción por los tribunales nacionales, constituyen un apoyo relevante para la apreciación de la autonomía del Derecho del comercio internacional, acerca de la cual, probablemente, se pueda afirmar se encuentra en fase de expansión y consolidación.

75 Reconociendo esta realidad, se ha señalado que los jueces estatales, por lo que a los conflictos comerciales se refiere, quedan relegados cada vez más a afrontar la inevitable 
en los tiempos actuales como consecuencia de la repercusión creciente de los usos comerciales internacionales facilitada por las recopilaciones o codificaciones y se traduce en la aplicación directa de los usos. Por otra parte, se ha producido la aparición de los denominados principios generales de la contratación mercantil internacional, cuya observancia habría de ser vigilada también directamente por los árbitros. Tales factores acentúan la autonomía del Derecho del comercio internacional en lo relativo a su aplicación.

Sin embargo, se debe señalar que, si bien cabe detectar una considerable y creciente dosis de autonomía, la culminación final del proceso de aplicación arbitral de las normas que lo integran continúa dependiendo del auxilio estatal, que se revela como absolutamente imprescindible para la ejecución de los bienes con cargo a los cuales el deudor condenado debe ser compelido a la satisfacción de su deuda. Así, aun cuando la discrecionalidad de los Estados en materia de reconocimiento y ejecución de laudos arbitrales haya disminuido en los últimos años y, aun cuando aquellos hayan adquirido compromisos para la eliminación de incertidumbres en la materia, la necesidad del reconocimiento estatal y la excepción de orden público acentúan la duda acerca de la autonomía del Derecho del comercio internacional.

Tomando en consideración tal conjunto de consideraciones, no parece pueda afirmarse actualmente, de modo categórico, la autonomía del derecho del comercio internacional. Incluso no cabe predicarla de la lex mercatoria, entendida en su sentido más restrictivo, es decir, integrada tan sólo por los usos internacionales y aplicada de modo exclusivo por árbitros. Tal afirmación tampoco puede ser hecha respecto de la acepción amplia de la lex mercatoria en la que cabe englobar el Derecho estatal convencional que regula aspectos jurídico-privados del comercio internacional mediante regulaciones uniformes.

Todo ello, sin embargo, no impide la afirmación de que el derecho del comercio internacional ha venido adquiriendo una especificidad que lo aleja y diferencia de los derechos internos. Por otra parte, las consideraciones anteriores no permiten fundamentar una posición negativa frente a la existencia de una sistemática de dicho derecho adecuada a la realidad efectiva de su objeto material. Por el contrario, todo ello aboga en favor del reconocimiento de una autonomía creciente del derecho del comercio internacional.

rutina de la ejecución del moroso recalcitrante o la represión del contumaz infractor de la ley nacional. Cfr. ILLESCAS ORTIZ, «Las mutaciones contemporáneas del derecho privado de la economía», en Homenaje a Barrera Graf, Universidad Nacional Autónoma de México, Tomo II, 1989, págs. 949 y sigs. 


\section{La contribución de los Estados y organizaciones internacionales}

Se ha venido haciendo referencia hasta ahora a un Derecho del comercio internacional únicamente emanado de los particulares, partícipes en las relaciones mercantiles internacionales. Sin embargo, también los Estados han contribuido de manera significativa al desarrollo del Derecho del comercio internacional, en particular en los últimos treinta años, con lo que tal disciplina jurídica se ha desarrollado y fortalecido, dando lugar, sin embargo, a una heterogeneidad que afecta a los orígenes y a la identidad formal de las normas conformadoras de aquél. Por su parte, algunas organizaciones internacionales interestatales, además de su labor preparatoria de tratados internacionales, producen textos meramente orientativos que carecen de todo poder obligacional cuyo impacto en la regulación de la realidad es, sin embargo, de todo punto innegable.

\section{A) Los Tratados y Convenciones}

Los Estados constituyen, y hay en ello una cierta paradoja teniendo en cuenta lo hasta ahora expuesto, una de las primeras fuentes de producción de normas comerciales uniformes pues, en virtud de su poder convencional, dan cuerpo a instrumentos internacionales de derecho del comercio internacional aplicables a actos y operaciones realizados en su territorio o a empresarios cuyo establecimiento principal radique en el mismo. La forma de actuar de los Estados cuando se trata de crear un nuevo instrumento comercial internacional es igual a la observada para la promulgación de tratados destinados a la regulación de otros tipos de cuestiones ${ }^{76}$.

Las convenciones y tratados internacionales constituyen las normas de mayor relevancia del Derecho del comercio internacional y, al mismo tiempo, las menos autónomas e independientes en su producción y aplicación. Al depender su establecimiento y vigencia de la voluntad de los Estados, nada deben a la sociedad global de mercaderes a la cual se le imponen. En la preparación de los tratados, los Estados actúan, en materia de Derecho del comercio internacional, bajo el impulso previo de las ya anteriormente mencionadas formulating agencies ${ }^{77}$, organizaciones internacionales de diversa configuración jurídica que llevan a

76 La Convención de Viena de 23 de mayo de 1969 sobre el derecho de los tratados. Sus textos presentan la característica de ser declarados por sus redactores abiertos permanentemente a la adhesión ulterior de otros Estados.

77 Cfr. supra, nota n. ${ }^{\circ} 30$. 
cabo la preparación del proyecto de convención que posteriormente será firmado por los Estados ${ }^{78}$.

Una característica significativa en alto grado que ostentan los tratados y convenciones dedicados al Derecho del comercio internacional es la decisiva relevancia otorgada a la voluntad de las partes en cuanto elemento determinante de la aplicación o inaplicación de la Convención de que se trate. De ello, constituyen ejemplos la Convención de Viena de 1980 y la Convención de las Naciones Unidas sobre garantías independientes y cartas de crédito stand-by, de 11 de diciembre de 1995. El primero de los citados instrumentos permite a las partes la total o parcial exclusión de la Convención de la regulación de su contrato ${ }^{79}$. El segundo otorga aún mayor relevancia a la voluntad de las partes, de manera que puede resultar de aplicación en una relación entre nacionales o residentes de países no signatarios de la Convención. La voluntad de las partes puede hacer que la Convención (art. 1, par. 2), resulte de aplicación a una garantía a la cual la Convención no resultaría de aplicación en virtud de los criterios contenidos en la misma. En sentido opuesto, resulta significativa la cláusula denominada opting out del art. 1, según la cual las partes tienen la posibilidad de sustraer la totalidad de su operación al imperio y aplicación de la Convención ${ }^{80}$, quedando el acuerdo entre las partes, en tal supuesto, sujeto al derecho interno de aplicación de acuerdo con los criterios conflictuales recogidos en los arts. 21 y 22. Correlativamente, el párrafo segundo del mismo art. 1 contempla la posibilidad de que las partes prefieran la sumisión a la Convención (opting in) de una garantía internacional que no

78 En el campo mercantil internacional, dos son los organismos que generalmente llevan a cabo tales tareas preparatorias: la Comisión de las Naciones Unidas para el Derecho mercantil internacional (UNCITRAL) y el Instituto Internacional para la Unificación del Derecho Privado (UNIDROIT). El UNIDROIT divide sus tareas preparatorias de reglas uniformes entre las dos ramas del Derecho privado, civil y mercantil; creada en 1926 como órgano auxiliar de la Sociedad de Naciones, fue reorganizada en 1940 como organización intergubernamental independiente compuesta por cincuenta y tres Estados miembros y con sede en Roma .

79 Es lo dispuesto en el art. 6 de la Convención de Viena de 1980: «Las partes podrán excluir la aplicación de la presente Convención o... establecer excepciones a cualquiera de sus disposiciones o modificar sus efectos». Vid. comentarios al respecto de DíEz PICAzo (dir.) La compraventa internacional de mercaderías. Comentario de la Convención de Viena, cit. págs. 45-49; asimismo, AUDIT, La vente commerciale de marchandises. Convention des Nations Unies du 11 avril 1980, cit. págs. 32 y sigs.

80 Art. 1, párrafo 2. ${ }^{\circ}$, de la Convención de las Naciones Unidas sobre garantías independientes y créditos documentarios stand-by, de 11 de diciembre de 1995: «This Convention applies also to an international letter of credit not falling within art. 2 if it expressly states that it is subject to this Convention». Cfr. STOufflet, La Convention des Nations Unies sur les garanties independantes et les lettres de credit stand-by, ... cit. pág. 133. 
constituye supuesto de garantía independiente o de carta de crédito stand-by ${ }^{81}$. A la inversa, de acuerdo con la previsión contenida en el art. 1 (1) (b)...unless the undertaking excludes the application of the convention, la voluntad de las partes puede, igualmente, excluir la aplicación de la Convención a una garantía si ésta expresa tal deseo de las partes.

\section{B) Las leyes modelo}

Son las organizaciones internacionales interestatales las que preparan el texto de una ley modelo ${ }^{82}$ que, a continuación, es presentado a los Estados para su utilización por éstos cuando se trate de promulgar una ley interna, sin que quepa aplicar el mecanismo de ratificación aplicable a los instrumentos internacionales. Se trata de un mecanismo similar al contemplado en el artículo 100 del Tratado de Roma constitutivo de la CEE (directivas comunitarias), aun cuando con la diferencia esencial de que la incorporación de la ley modelo a su ordenamiento interno no resulta obligatoria para los Estados.

Las leyes modelo constituyen un instrumento indicador de las pautas a seguir en materia de uniformización del Derecho del comercio internacional. Los Estados gozan de una amplia libertad, pues son libres para adecuar su legislación nacional a la ley modelo. El Estado podrá adoptar como ley interna la ley modelo en su integridad o una o varias de sus partes, integrando el texto mediante soluciones internas o, podrá preferir la existencia de lagunas en su derecho interno respecto del tratamiento que la ley modelo hubiere dispensado a la materia en ella regulada. El legislador estatal podrá colmar las lagunas que hubiere detectado en la ley modelo promulgando normas nacionales más allá de las propuestas armonizadoras fijadas en el modelo. El tenor literal de la ley modelo no obliga al legislador nacional, quien podrá adecuar la redacción del texto uniformador a las peculiaridades de su derecho.

Este modo de operar de las leyes modelo se desprende de los textos mediante los que se produjo la aprobación y recomendación de las más caracterizadas de entre ellas y que forman parte importante del Derecho del comercio internacional. La UNCITRAL ${ }^{83}$ ante la aprobación de

81 Ibidem, pág. 133.

$82 \mathrm{Al}$ respecto, vid. la exposición de Goode, Reflections on the harmonisation of commercial law, cit. pág. 57; asimismo, SснміттноғF se refiere en diversas ocasiones a la cuestión, en especial The codification of the law of international trade, cit. págs. $243 \mathrm{y}$ sigs. e ILLESCAS ORTIZ, art. cit. págs. 76-78.

83 Sesión de la UNCITRAL n. ${ }^{\circ}$ 484, de 15 de mayo de 1992, en la que se aprobó la ley modelo sobre transferencias internacionales de crédito, en Informe de la Comisión de Naciones Unidas para el derecho Mercantil Internacional sobre la labor realizada en su $25 .^{\circ}$ 
la ley modelo sobre transferencias internacionales de crédito, se permitió recomendar: «...que todos los Estados den la debida consideración a la Ley Modelo de la Comisión de las Naciones Unidas para el Derecho Mercantil Internacional sobre transferencias internacionales de crédito cuando sancionen o reformen sus leyes, habida cuenta de la necesidad contemporánea de uniformar el derecho aplicable a las transferencias internacionales de crédito» ${ }^{84}$.

En tales condiciones, se habrá de concluir que la fuerza uniformadora de estos documentos parece reducida. Los Estados son soberanos y libres para decidir adoptarlos o no y, además, caso de una decisión favorable a la adopción o transposición nacional de una ley modelo, dicha adopción puede ser diferente en intensidad, extensión y tenor literal en los diferentes Estados.

C) Los principios generales para la regulación de la contratación comercial internacional

Los principios generales reguladores de la contratación comercial internacional y sus funciones son ya una realidad en los momentos actuales, y disponen de un definitivo perfil tras la publicación por UNIDROIT, en 1995, de los Principios sobre los Contratos Comerciales Internacionales, texto concreto y único, a diferencia de los hasta ahora

período de sesiones, 4 a 22 de mayo de 1992, Asamblea General. Documentos Oficiales (Doc. A/47117), Naciones Unidas, Nueva York, 1992, págs. 21 y sigs. Como indicio de la evolución favorable de la opinión pública internacional acerca de los progresos del derecho del comercio internacional, se puede comparar el texto transcrito con el acordado en 1985 por la UNCITRAL, siete años antes, relativo a la Ley Modelo sobre Arbitraje Comercial Internacional, en el que se invitó a la Asamblea General de las Naciones Unidas a que «recomendase a los Estados que tuviesen en cuenta la ley modelo al promulgar o revisar sus leyes, a fin de satisfacer las necesidades existentes en materia de arbitraje comercial internacional», en Comisión UNCITRAL, Anuario, vol. XVI, 1985, Nueva York, págs. 42 y sigs. Por su parte, la Asamblea General se limitó a recomendar a los Estados «que examinen debidamente la Ley Modelo sobre Arbitraje comercial internacional, teniendo en cuenta la conveniencia de la uniformidad del Derecho procesal arbitral...». (Resolución de la Asamblea General, 11 de diciembre de 1985), ibidem, págs. 51-52.

84 Esta forma de operar de las leyes modelo fue respaldada por el Secretario General de Naciones Unidas, quien, con ocasión de la consideración del proyecto de una de las leyes modelo preparadas por UNCITRAL, indicó de modo literal que «el método de tipificar y mejorar las leyes nacionales... es el de una ley modelo. El texto... será recomendado... a todos los Estados para que lo incorporen a sus respectivas legislaciones». Cfr. Informe del Secretario General (Doc. A/CN.9/264), en Anuario, Comisión de las Naciones Unidas para el Derecho Mercantil Internacional, vol. XVI, 1985, págs. 109 y sigs. Vid. Goldstajn, Reflections on the structure of the modern law of international trade, cit. págs. 15-16. 
mencionados que representan un tipo o grupo de textos. Su culminación ha supuesto una ardua tarea para su identificación, recopilación y formulación escrita, así como en orden a la fijación de las condiciones de su utilización por contratantes y árbitros, así como por los tribunales internos.

Su Preámbulo, dedicado a la enunciación del Propósito de los Principios, establece:

«Estos Principios establecen reglas generales aplicables a los contratos mercantiles internacionales.

Ellos deberán aplicarse cuando las partes hayan acordado someter el contrato a sus disposiciones.

Estos Principios pueden aplicarse cuando las partes hayan acordado que el contrato se rija por los «principios generales del derecho», la lex mercatoria o expresiones semejantes.

Estos Principios pueden proporcionar una solución a un punto controvertido cuando no sea posible determinar cuál es la regla (rule) de derecho aplicable a dicho contrato.

Estos Principios pueden ser utilizados para interpretar o suplementar textos internacionales de derecho uniforme.

Estos Principios pueden servir de modelo para la legislación a nivel nacional o internacional».

El texto ${ }^{85}$ contiene un amplio y completo catálogo de principios de índole contractual, que permite su comparación con la tradicional teoría del negocio jurídico de los ordenamientos internos, habiendo quedado excluidas, únicamente, aquellas cuestiones que hubieran podido entrañar demasiada cercanía a la concepción en materia de orden público. 1) Entre las Disposiciones Generales (Capítulo I), se recogen principios relativos a la libertad de contratación, libertad de forma, o la buena fe y

85 Cfr. Instituto Internacional para la Unificación del Derecho Privado, (UNIDROIT) Principios sobre los Contratos Comerciales Internacionales, Roma, 1995. Al respecto, vid. Institute of International Business and Practice, UNIDROIT, Principles for International Commercial Contracts: a New Lex Mercatoria?, Publicación CCI, n. ${ }^{\circ} 490$ /1, 1995; Bonell, A New Approach to International Commercial Contracts: the UNIDROIT Principles of International Commercial Contracts, Kluwer Law International, 1999; las colaboraciones de FARnSwORTH, BONELl, GARRO, LANDO, todas ellas en el número especial de Tulane Journal of International and Comparative Law, vol. 3, 1995; asimismo, FONTAINE, Les principes pour les contrats commerciaux internationaux élaborés par UNIDROIT, en Rev. de droit international et de droit comparé, 1991, págs. 23-40; GiARDINA, «Les Principes UNIDROIT sur les contrats internationaux», en Journal du Droit International, 1995, págs. 547-558; en la doctrina española, Morán Bovio (Coordinador) Comentario a los Principios de UNIDROIT para los Contratos del Comercio Internacional, Aranzadi, 1998. 
lealtad negocial. 2) Su Capítulo II está dedicado a la formación del contrato, e incluye principios relativos a la formulación de la oferta, su revocación, rechazo y aceptación; otros relativos a las condiciones a que pueda estar sujeto el contrato, y principios relativos a la utilización de cláusulas tipificadas. 3) La validez del contrato es contemplada en el Capítulo III, en el que se definen conceptos tales como el de error, dolo o error determinante, y se recogen principios definitorios del equilibrio contractual y de la desproporción de las prestaciones contractuales. 4) En el Capítulo IV se incluyen los principios relativos a la interpretación del contrato comercial internacional. 5) El Capítulo V contiene los principios dedicados al contenido del contrato, estableciendo los dedicados a las obligaciones expresas e implícitas, el principio de cooperación entre las partes, la obligación de resultado y los criterios para la determinación de la calidad de la prestación y la determinación del precio. 6) Los principios generales relativos al cumplimiento del contrato internacional están contenidos en el Capítulo VI, relativos al lugar y al momento del cumplimiento, pudiendo ser éste instantáneo o dilatado en el tiempo. Igualmente, se incluyen criterios para la apreciación de la excesiva onerosidad (hardship). 7) Por último, el Capítulo VII incluye los principios o criterios generales dedicados al incumplimiento del contrato, regulando lo relativo a su concepto general, su subsanación, plazos, cláusulas de exoneración y fuerza mayor. Asimismo, se contemplan el derecho a exigir el cumplimiento, el derecho a dar por terminado el contrato estableciendo lo relativo al incumplimiento anticipado, así como las garantías adecuadas de cumplimiento y el resarcimiento derivado de dicho incumplimiento ${ }^{86}$.

\section{D) Las guías jurídicas}

Las guías jurídicas se elaboran con la finalidad de establecer un cuadro jurídico apropiado para que las partes en un contrato internacional fijen de común acuerdo el contenido obligacional del mismo. A diferencia de los anteriores instrumentos, las guías jurídicas no ofrecen a los contratantes un articulado preciso ni un conjunto de reglas objetivamente formuladas a las que someterse. Las guías contemplan las cuestiones y materias de mayor importancia sobre las que las partes han de

86 Acerca del éxito que parecen haber experimentado los Principios, vid. BonELL, «The UNIDROIT Principles in Practice. The Experience of the First Two Years», en Uniform Law Revue, 1997, págs. 34-45. El autor se hace eco del que parece ser gran respaldo dispensado por la doctrina, y hace referencia a una serie de laudos arbitrales y, muy en particular, de sentencias de los tribunales internos de una serie de países, tales como Alemania, Austria y Suiza. 
conseguir un acuerdo y una solución convencional para dichos problemas desde una posición justa y equitativa, pudiendo contener propuestas de estipulaciones concretas ${ }^{87}$.

Los contratantes deben expresar su voluntad relativa a cada una de las cuestiones relevantes y deben redactar la cláusula contractual adecuada a su voluntad, auxiliados por la guía. La guía ofrece un adecuado auxilio retórico y sustantivo a la hora de manifestar su voluntad y forma de expresarla. Las partes pueden optar por adoptar, como contenido de su contrato, el contenido en la guía. Igualmente, las partes pueden insertar cláusulas distintas a las contenidas en la guía, o no estipular nada sobre la materia en cuestión ${ }^{88}$.

En este sentido, sirve de ejemplo la guía de UNCITRAL Guide on drawing up contracts for large industrial works ${ }^{89}$, la cual se pronuncia precisando su valor jurídico, afirmando en su introducción que «la Guía no tiene valor normativo propio; trata simplemente de ayudar a las partes en la negociación y redacción de su contrato. Las diversas soluciones a las cuestiones examinadas en la Guía no regirán la relación entre las partes a menos que éstas convengan expresamente en esas soluciones y las estipulen en el contrato».

Las guías son instrumentos de escaso poder armonizador sobre el Derecho del comercio internacional, pues dependen de la voluntad de quienes participan en operaciones comerciales internacionales. Las recopilaciones y las condiciones generales dejan mayor libertad a los contratantes y aparecen como medios armonizadores más contundentes. Las guías jurídicas, por contra, requieren en su uso una constante determinación de la voluntad de los contratantes sobre cada una de las cuestiones en ellas contempladas y sobre la disciplina convencional aconsejada para cada una de aquéllas por el propio texto auxiliar.

87 De entre ellas, son las más significativas: Guide on drawing up contracts for large industrial works, United Nations, New York, 1973, Documento, A/CN.9/SER.B/2, n. ${ }^{\circ}$ E.73.II.E; UNCITRAL Legal guide on electronic funds transfers, Naciones Unidas, Nueva York, 1987, Documento A/CN.9/SER.B/1); Guide for drawing up international contracts between parties associated for the purpose of executing a specific project, United Nations, New York, 1979, n. ${ }^{\circ}$ E.79.II.E.22; Guide on drawing up international contracts on industrial cooperation, United Nations, New York, 1976, n. ${ }^{\circ}$ E.76,II,E.14.

$88 \mathrm{Al}$ respecto, es de interés Schmiтtноғ, The unification or harmonisation of law by means of standard contracts and general conditions, cit. especialmente págs. 197-198. El autor pone de relieve que la comunidad de comerciantes utiliza este mecanismo en actividades todavía carentes del necesario grado de uniformidad, de modo que no resulta adecuado proceder a la tipificación del contrato. Se aprecia una especie de gradación entre los diferentes mecanismos uniformizadores.

89 «Guía jurídica de la UNCITRAL para la redacción de contratos internacionales de construcción de instalaciones industriales», cit. traducción al castellano, cit. pág. 1. 


\section{El contenido del Derecho del comercio internacional}

Es siempre necesario, en relación con cualquier disciplina jurídica, definir y acotar su contenido de manera sistematizada. La cuestión resulta particularmente problemática en lo que se refiere al Derecho del comercio internacional en el que, de un lado, frecuentemente, se insertan normas ajenas a las características esenciales de aquél y, de otro, la apreciación de la diferente naturaleza de las normas que lo componen lleva a la negación de cualquier posibilidad de sistematización del mismo.

\section{Los caracteres del Derecho del comercio internacional y las normas que lo integran}

Las normas que integran el contenido del Derecho del comercio internacional, aun marcadas por la heterogeneidad de su forma externa y de su procedencia, persiguen como objetivo esencial, la consecución de una regulación uniforme para las relaciones contempladas y, por otra parte, resultan ser normas de inspiración exclusivamente privatista. De ello se sigue la imposibilidad de considerar como parte del Derecho del comercio internacional a las normas que integran los sistemas conflictuales, así como a aquellas normas, reconducibles al Derecho público, mediante las que los Estados organizan los intercambios comerciales internacionales.

\section{A) La uniformidad reguladora pretendida: la exclusión del sistema conflictual como integrador del Derecho del comercio internacional}

La uniformidad en el tratamiento jurídico a dispensar a las relaciones reguladas por el Derecho del comercio internacional es una aspiración esencial y constituye acusado rasgo diferenciador del mismo. $\mathrm{Su}$ objetivo consiste en establecer una regla única, de validez potencialmente universal, para disciplinar una conducta internacional, cualquiera que sea la nacionalidad de las partes obligadas, el lugar de la prestación o la situación de la cosa.

La uniformidad constituye aspiración y carácter consubstancial al Derecho del comercio internacional, pues las reglas que lo integran son uniformes en el momento de su formulación y necesitan de la uniformidad a la hora de su aplicación. Esta exigencia parece imprescindible al tratarse de reglas con una vigencia potencialmente global que han de ser aplicadas por tribunales de jurisdicciones diversas. La uniformidad es, pues, una aspiración que, ya desde su inicio, trata de satisfacer la norma 
que integra el Derecho del comercio internacional, y es también un requisito a satisfacer en su aplicación universal. En atención a estas consideraciones, se suelen establecer en los propios instrumentos internacionales que constituyen el Derecho del comercio internacional disposiciones como la siguiente: «La presente Convención regula exclusivamente la formación del contrato de compraventa y los derechos y obligaciones del vendedor y del comprador, dimanantes de ese contrato...» ${ }^{90}$, precepto éste que pone de manifiesto el carácter material y uniforme de las reglas que integran la Convención a la que pertenece; o bien, «En la interpretación de la presente Convención se tendrá en cuenta su carácter internacional y la necesidad de promover la uniformidad en su aplicación...» ${ }^{91}$, lo que pone de manifiesto el carácter de uniformidad que se pretende cuando se da cuerpo a normas que se integran en el Derecho del comercio internacional. El precedente medieval de uniformidad jurídica presente en la lex mercatoria ha gravitado siempre sobre la mente de los creadores del Derecho del comercio internacional.

El tratamiento jurídico uniforme buscado implica una innovación que se pone de manifiesto si se comparan sus resultados con los obtenidos mediante la aplicación de las técnicas conflictuales anteriores a la aparición del Derecho del comercio internacional. Dicha técnica anterior, con la que convive ${ }^{92}$, es una técnica de solución de controversias,

90 Art. 4 «Convención de las Naciones Unidas sobre los contratos de compraventa internacional de mercaderías», hecha en Viena el 11 de abril de 1980, BOE de 30 de enero de 1991: «La presente Convención regula exclusivamente la formación del contrato y los derechos y obligaciones del vendedor y del comprador dimanantes de ese contrato».

91 Art. 7 (I) de la Convención de Viena de 1980. Igualmente, art. 6 (1) de la Convención de UNIDROIT, Ottawa, 28 de mayo de 1988 y art. 4 (1) Convención de UNIDROIT sobre factoring, Ottawa, 28 de mayo de 1988. El citado precepto reza: «Pour l'interpretation de la presente Convention, il será tenu compte de...son caractere international et de la necessité de promovoir l'uniformité de son application». El mismo pronunciamiento se contiene en el art. 14 del Convenio de las Naciones Unidas sobre la responsabilidad de los empresarios de terminales de transporte en el comercio internacional, Viena, 19 de abril de 1991.

92 De ello discrepa FERNÁNDEZ Rozas, «Consideraciones en torno a la relevancia del derecho uniforme en la regulación del tráfico privado externo», cit. págs. 5227 y sigs. Igualmente FERNÁNDEZ ROZAS (editor), «Derecho del comercio internacional», cit. que incluye normas de conflicto como integrantes del derecho del comercio internacional; este planteamiento igualmente se separa de ESPINAR VICENTE, «Notas para una reflexión sobre las enseñanzas del Derecho mercantil internacional», en Estudios Jurídicos en Homenaje al Profesor Aurelio Menéndez, Tomo I, Madrid, Civitas, 1996, págs. 321-338, trabajo en el que el autor entremezcla derecho uniforme y sistema conflictual; por su parte, FERNÁNDEZ DE LA GÁNDAra y Calvo Caravaca, Derecho Mercantil Internacional, Madrid, Tecnos, 1993, incluyen temas de derecho comunitario europeo. Vid. ILLESCAS OrTIZ, art. cit. págs. 45-47. La convivencia entre el derecho uniforme y el sistema conflictual perdurará. De una parte, la consideración histórica del sistema conflictual como sistema ordinario de solución de controversias 
no de prevención de ellas, pues es un derecho que se basa en el sistema conflictual por contraposición al Derecho del comercio internacional. Frente a tal sistema, el Derecho del comercio internacional muestra una mejor adecuación a las necesidades del tráfico internacional, pues satisface la exigencia del conocimiento previo por las partes acerca del alcance de las obligaciones asumidas y de los derechos ostentados. Por otra parte, el Derecho del comercio internacional especifica anticipadamente la jurisdicción que lo ha de aplicar. En suma, es un derecho previsor, y no meramente resolutivo. Está compuesto por un conjunto de reglas sustantivas o materiales que establecen el régimen jurídico de las operaciones de comercio internacional sometidas al mismo. Es, por tanto, un sistema material y no adjetivo o formal, pues las normas que lo integran no remiten a otras disposiciones nacionales, sino que disciplinan directamente la materia contemplada.

No se opone a lo anterior el hecho de que diferentes textos integradores del Derecho del comercio internacional contengan, precisamente, criterios de índole conflictual ${ }^{93}$. De un lado, los criterios conflictuales contenidos en el instrumento internacional pueden tener por objetivo proporcionar el tratamiento jurídico completo al contrato de que se trate en lo relativo a cuestiones reconducibles a la teoría general del negocio jurídico. De otro, la uniformidad, aun siendo objetivo irrenunciable, requerirá un proceso evolutivo expansivo de paulatina decantación hasta su imposición definitiva. Sistema conflictual y Derecho del comercio internacional responden, en suma, a objetivos y orientaciones de fondo contrapuestos.

B) El carácter privado de las normas que integran el Derecho del comercio internacional: la exclusión de las normas de Derecho público reguladoras del tráfico económico

La actividad del comercio internacional es también afectada por normas de Derecho público ${ }^{94}$, constituido por los acuerdos y conven-

\footnotetext{
internacionales; de otra, el derecho uniforme se construye con lentitud, por la propia naturaleza y condición de sus fuentes. Además, el derecho uniforme es parcial y carece de normas generales. Por otra parte, el sistema de normas de conflicto crece en virtud de articulares intervenciones legislativas: vgr. Ley de 8 de octubre de 1980 sobre el contrato de seguro contiene unas «Normas de Derecho Internacional Privado», arts. 107-109, de resultas de la ley de 19 de diciembre de 1990, para adaptar el derecho español a la Directiva 88/357/CEE.

93 Así sucede, vgr., con los arts. 21 y 22 de la Convención de las Naciones Unidas sobre garantías independientes y créditos documentarlos stand-by, de 11 de diciembre de 1995.

94 El comercio internacional se encuentra sometido generalmente a dos órdenes netamente diferenciadas de normas jurídicas. En primer término, existen unas normas de carác-
} 
ciones entre los diferentes Estados, en cuya virtud las mercancías circulan entre ellos con plena libertad o con determinadas restricciones cuantitativas o arancelarias, lo que asimismo sucede respecto de la prestación de servicios internacionales y de la circulación de capitales entre los diferentes Estados. El Acuerdo General sobre Aranceles y Comercio (GATT) constituye el núcleo del Derecho público del comercio internacional ${ }^{95}$, el cual contiene, especialmente en materia de servicios y capitales, una multitud de acuerdos bilaterales entre los Estados destinados a permitir flujos recíprocos y a fijar las cuantías y condiciones de dichos flujos.

Este Derecho público del comercio internacional no forma parte del Derecho del comercio internacional. Las normas que integran tal disciplina tienen un objetivo más limitado y no aspiran a regular la soberanía económica de los Estados. Tales normas pretenden que los Estados permitan la regulación de la actividad internacional de sus ciudadanos, personas físicas o jurídicas. Se trata, pues, de un orden jurídico-privado que se limita a disciplinar las relaciones entre los individuos que, en el marco de los flujos comerciales establecidos por los Estados mediante normas de Derecho público, celebran contratos con ánimo de participar en la circulación de bienes, servicios y capitales que dichos flujos generan o permiten. Por tanto, el Derecho del comercio internacional se compone de normas que regulan las relaciones mercantiles internacionales entre partes privadas, y no guarda relación con el ejercicio de los poderes soberanos por parte de los Estados. En consecuencia, cuestiones relativas al régimen aduanero, tipos de cambio, flujos monetarios y comerciales, balance de cuentas públicas, son cuestiones, entre otras, sobre las que el Derecho del comercio internacional no ejerce ningún efecto.

Frente a ello, se debe poner de relieve la calidad iusprivatista del Derecho del comercio internacional, ajeno por tanto al Derecho públi-

ter jurídico público, en sentido estricto, conforme a las cuales los poderes públicos trazan el marco regulador de la actividad de los particulares. En segundo lugar, existen normas que disciplinan la actuación libre de los particulares que operan en el mismo. Aun cuando los criterios para establecer la conceptuación de unas y otras normas son numerosos y la frontera entre ambos géneros de disposiciones oscuras e imprecisas, se suele denominar a las primeras aludidas como integrantes del Derecho público y a las segundas como componentes del Derecho privado. Vid. ORTIZ ARCE (Coordinador), Legislación comercial internacional, Tecnos, Madrid, 1997. A pesar del título indicado, bajo el mismo el citado volumen contiene el derecho público del comercio internacional.

95 Es muy amplia la literatura sobre el GATT y otros organismos internacionales encargados de la cuantificación y liberalización económica del comercio internacional. Al respecto, pueden verse FERNÁNDEZ RozAS (editor) Derecho del comercio internacional cit. págs. 53-79; de forma más especializada, Avila, UrRutia y DíAz Mier, Regulación del comercio internacional tras la Ronda Uruguay, Madrid, Tecnos, 1994. 
co. Tal carácter aparece en algunos de los instrumentos internacionales ya mencionados, tal como el artículo 4, par. 1, de la Convención de Viena de $1980^{96}$, que regula la formación del contrato y de los derechos y obligaciones del vendedor como objeto de la Convención, con lo que es claro que no pretende la regulación de aspectos de la cosa vendida ni lo relativo a los medios para el abono del precio, puesto que ello se regirá por las disposiciones de carácter público vigentes en el lugar de entrega de la mercancía o en el lugar de pago del precio. El carácter privado queda puesto de manifiesto igualmente en otros textos del Derecho del comercio internacional: «Ninguna de las disposiciones de la presente Convención impedirá a los Estados contratantes aplicar los reglamentos sobre control de cambios vigentes en sus territorios, y sus disposiciones relativas a la protección de su moneda, incluidos los reglamentos aplicables en virtud de acuerdos internacionales de los que sean partes» ${ }^{97}$.

\section{La sistematización del Derecho del comercio internacional}

Se puede intentar la construcción de una sistemática del Derecho del comercio internacional adecuada a la realidad efectiva de su objeto material, es decir, el mencionado comercio internacional. La admisibilidad de la sistematización del Derecho del comercio internacional no ha sido aceptada hasta ahora, pues la doctrina ha negado generalmente la existencia de un sistema. La adjetivación de las normas que integran el Derecho uniforme como reglas «lagunares» o «contradictorias», la afirmación acerca de la carencia de sistema, o su carácter incompleto ${ }^{98}$, la utilización de otras expresiones tales como unsystematic, complex and multiform $^{99}$, todo ello pone de relieve la percepción de la doctrina de los diversos países contraria a la posible índole sistemática del Derecho del comercio internacional. Ello se ha debido a la dificultad ini-

96 Art. 4 «Convención de las Naciones Unidas sobre los contratos de compraventa internacional de mercaderías», cfr. supra, nota n. ${ }^{\circ} 86$.

97 Art. 76, par. 1, de la Convención sobre letras de cambio y pagarés internacionales, Nueva York, 9 de diciembre de 1988, establece las consecuencias que se derivan de una norma de derecho público reguladora de la materia monetaria sobre la obligación de pago del aceptante de la letra de cambio internacional. Por su parte, el art. 54 de la Convención de Viena de 1980 establece que «La obligación del comprador de pagar el precio comprende la de adoptar las medidas y cumplir los requisitos fijados por el contrato o por las leyes o los reglamentos pertinentes para que sea posible su pago». Se trata de normas que no interfieren en las normas estatales en materia de control de cambios.

98 Cfr. GondRA, art. cit. pág. 23

99 Cfr. Schmitthoff, The Unification of the Law of International Trade, cit. pág. 212. 
cial del análisis de las reglas uniformes, pues estas reglas van apareciendo poco a poco, poseen procedencias dispares y se someten a formulaciones de diversa naturaleza ${ }^{100}$.

Sin embargo, transcurridos estos últimos años, no puede mantenerse tal conclusión. La evolución del Derecho del comercio internacional debe ser comparada con la evolución que los intercambios internacionales han experimentado en las dos pasadas décadas. Por ello, puede afirmarse que, hoy en día, el panorama que ofrecen las normas que integran el Derecho del comercio internacional no es tan asistemático ni tan incompleto. Por el contrario, se encuentra integrado en la actualidad por un conjunto de reglas que, a pesar de su variada naturaleza, cubren buena parte de las realidades y exigencias materiales que el comercio internacional plantea. Asimismo, los intercambios internacionales de bienes y servicios disponen de regulaciones derivadas de convenios de amplia aceptación y, alrededor de unas y otros, una tupida red de disposiciones diversas regulan facetas accesorias y complementarias.

Aun así, se impone el reconocimiento de que el Derecho del comercio internacional no es una disciplina jurídica absolutamente decantada, sino afectada de provisionalidad y de ciertos grados de debilidad. La provisionalidad se manifiesta en que determinadas normas integradoras de aquél se encuentran aún inmersas en el proceso de aceptación de las mismas con lo que no ostentan vigencia. Algunas de estas disposiciones han sido aprobadas por la Asamblea General de Naciones Unidas, si bien, dado el insuficiente número de ratificaciones recibidas hasta el momento presente, no se encuentran todavía en vigor, mientras que otras sólo han recibido hasta el momento firmas sin haber recibido ratificación alguna; otras son aún meros proyectos ${ }^{101}$.

100 Vid. IllesCas Ortiz, art. cit. pág. 88. Una visión y un juicio acerca de tal conjunto normativo, llevada a cabo hace veinte años, no podía arrojar otra conclusión sino la que los autores han formulado.

101 Sin embargo, la propia existencia de estos últimos demuestra la virtualidad de un sistema jurídico lo suficientemente elaborado como para detectar las necesidades de la realidad disciplinada, comprobar las lagunas normativas existentes y organizar el procedimiento de satisfacción de aquéllas mediante el colmo de éstas. El Derecho del comercio internacional se resiente, precisamente, de la debilidad que su carácter internacional conlleva. La ratificación de las normas convencionales que lo integran depende de la voluntad legislativa de los Estados, dotados de una soberanía sometida al embate de la interdependencia y la integración regional, con lo que la difusión geográfica del Derecho del comercio internacional se encuentra condicionada. Por otra parte, en lo que se refiere a las normas consuetudinarias y de inferior rango que lo integran, la excepción de orden público ya aludida constituye siempre un obstáculo jurídico que la regla jurídica uniforme ha de sortear en la mayoría de los casos. Cfr. GoldSTAJn, Reflections on the Structure of the Modern Law of International Trade, cit. págs. 17 y sigs. 
A pesar de ello, se puede considerar la existencia en la actualidad del Derecho del comercio internacional y la posibilidad de su sistematización ${ }^{102}$, fundamentada, en una primera consideración, en la apreciación de la circulación internacional de bienes y servicios cuyo núcleo está constituido por el contrato de compraventa. Junto a la regulación a propósito de este último, coexisten normas sobre la financiación de la cosa vendida o suministrada; a continuación, dado el carácter internacional de la relación principal, el transporte internacional ocupa el lugar siguiente en cuanto actividad asociada a la entrega de la cosa; por otra parte, el pago del precio, sus instrumentos y sus garantías suponen la contraprestación a la entrega, por lo que tal índole de problemas compone el capítulo siguiente de la sistemática; por último, la solución de controversias mediante el recurso a los tribunales arbitrales constituye el elemento final del sistema del Derecho del comercio internacional.

En cada grupo se integran normas uniformes diversas, emanadas de distintas fuentes, dotadas de diferente naturaleza y en fase evolutiva, contempladas desde una perspectiva universal, pero ello no impide que pueda intentarse su sistematización.

1. ${ }^{\circ}$ ) El primer cuerpo de normas es el dedicado a la promulgación de principios generales, de índole teórica básica, para la regulación del conjunto de la contratación internacional, compuesto por los Principios Generales reguladores de la Contratación Internacional (UNIDROIT, 1995).

$\left.2 .^{\circ}\right)$ El segundo es el compuesto por las normas dedicadas al contrato internacional de compraventa, en cuanto contrato paradigmático de las relaciones mercantiles internacionales, así como las normas reguladoras de otros contratos afines.

A) En primer lugar, la Convención de Viena de 1980, que resulta complementada $1^{\circ} .^{\circ}$ ) por los Incoterms 2000, relativos a las mo-

102 La sistematización que sigue está inspirada en dos trabajos de Schmiтthoff, «The unification or harmonisation of law by means of standard contracts and general conditions» cit. y «The law of international trade» cit., ambos en Select Essays cit., respectivamente págs. 188-205 y 219-230. Asimismo, se inspira en buena medida, aunque no completamente, en la clasificación hecha por Goode, «Reflections on the harmonisation of commercial law», en Revue de Droit Uniforme - Uniform Law Revue, 1991, I, págs. 54 y sigs. pues el citado autor da cabida a normas de derecho comunitario europeo, que no forman parte, por regionales, del derecho del comercio internacional. Se ha tenido en cuenta, igualmente, la clasificación de GOLDSTAJN, Reflections on the structure of the modern law of international trade, cit. pág. 16. En los citados autores se encuentra asimismo inspirada la sistemación de ILLESCAS ORTIZ, art. cit., págs. 90-91. 
dalidades de entrega, y $\left.2 .^{\circ}\right)$ por la Convención sobre la Prescripción de 1974.

B) La regulación uniforme de otros contratos internacionales similares o afines, entre los que se deben tener en cuenta la construcción de plantas industriales y su Guía Jurídica de UNCITRAL; el denominado comercio compensatorio internacional y su Guía Jurídica de UNCITRAL, así como los contratos con entes públicos.

3. $\left.{ }^{\circ}\right)$ El tercer grupo de normas es el dedicado a la financiación del comercio internacional, entre las que cabe hacer mención de:

A) La Convención de Naciones Unidas de 1988 sobre letras de Cambio internacionales y pagarés internacionales, Nueva York, 1988

B) La Convención de UNIDROIT de 1988 sobre leasing internacional.

C) La Convención de UNIDROIT de 1988 sobre factoring internacional.

4. $\left.{ }^{\circ}\right)$ El cuarto grupo es el relativo a la regulación del transporte internacional de mercancías:

A) El transporte marítimo: el Convenio de Bruselas, de 1924, y las Reglas de Hamburgo, 1978.

B) El transporte aéreo: el Convenio de Varsovia de 1929 y sus epígonos.

C) El transporte multimodal y la Convención de 1980.

D) Las terminales de transporte y su responsabilidad internacional. La Convención de Viena de 1991.

5. $\left.{ }^{\circ}\right)$ El quinto grupo se refiere al pago de las transacciones internaciones y a las garantías prestadas a propósito de las mismas.

A) Los créditos documentarios (RUU).

B) El pago por medios electrónicos: guía jurídica y ley modelo de UNCITRAL.

C) Las garantías a primera demanda y sus diversas modalidades: las Reglas Uniformes de la CCI y la Convención de UNCITRAL.

6. ${ }^{\circ}$ ) El sexto y último grupo contempla la solución de controversias:

A) El arbitraje comercial internacional, materia en la que son de destacar: la Convención de Nueva York de 1974; la Convención 
de Ginebra de 1961; la Ley modelo de UNCITRAL sobre arbitraje comercial internacional y el reglamento de arbitraje de UNCITRAL.

B) La conciliación comercial internacional: el Reglamento de conciliación de UNCITRAL.

\section{Derecho internacional privado y Derecho del comercio internacional}

La criticada insuficiencia del sistema conflictual para la regulación de las relaciones mercantiles internacionales y la eclosión del Derecho del comercio internacional pueden ser utilizadas para fundamentar una crítica contra el derecho internacional privado. Por el contrario, ponen de manifiesto una nueva concepción del derecho internacional privado, que no puede ser entendido como sinónimo de sistema conflictual.

Es forzoso reconocer la existencia de concepciones diferentes acerca del derecho internacional privado. Resultan unas ser más restringidas, en especial la sostenida por el derecho alemán y por el derecho italiano, si bien esta última no es tan restringida como la primera; otras le otorgan un alcance más amplio, entre las que destaca la sostenida por la doctrina francesa que ejerce influencia destacada sobre un amplio sector de las doctrinas de distintos países europeos y que, asimismo, recibe un respaldo mayoritario de la doctrina española. En su calidad de exponentes distinguidos de la doctrina francesa, definen Batiffol y Lagarde el objeto del derecho internacional privado como l'ensamble des règles applicables aux seules personnes privés dans les relations de la societé internationale ${ }^{103}$.

En aplicación de tal concepción, pone de relieve Batiffol, a propósito de las relaciones mercantiles internacionales, la paradoja de que el derecho internacional privado se ha desarrollado en mucha mayor medida en lo relativo a los problemas de familia y de los bienes que en lo relativo a las relaciones mercantiles. Ello se debe a un interés demasiado exclusivo por un modo determinado de regulación de las relaciones privadas internacionales, cual es el sistema conflictual. En lógica consecuencia de lo anterior, prosigue el citado autor, las relaciones mercantiles, que han existido siempre, no han sido suficientemente consideradas por los internacionalistas de derecho privado, incluso en

103 Vid. Batiffol y Lagarde, Droit International Privé, LGDJ, París, 8. a edición, pág. 17; en igual sentido Audit, Droit International Privé, París, Economica, págs. 14 y sigs. defiende, asimismo, una concepción amplia (élargie) al respecto. 
aquellos países que no identifican el derecho internacional privado con los conflictos de leyes ${ }^{104}$.

Esta concepción amplia acerca del Derecho Internacional Privado es la que asimismo parece obtener un mayor respaldo en el ámbito de la doctrina española ${ }^{105}$. Siguiendo la exposición de Aguilar Navarro, pone de relieve Carrillo Salcedo la conexión real y sociológica que existe entre los problemas incluidos dentro del objeto del Derecho internacional privado, pese a la heterogeneidad igualmente apreciable entre los mismos, «en cuanto todos ellos responden al fundamento mismo y a la razón de ser del Derecho internacional privado, cual es el problema que crea la presencia del hombre y de su vocación ecuménica en un mundo parcelado política y jurídicamente». De forma similar, González Campos, cuya posición es seguida por Pérez Vera, justifica la concepción amplia por la unidad finalista de los temas tratados para la adecuada reglamentación del tráfico externo, así como desde una consideración «estructural» del Derecho internacional privado «como conjunto de respuestas jurídicas a las situaciones privadas internacionales, que exige tener en cuenta las relaciones y condicionamientos existentes entre las diferentes materias».

De manera determinante, Carrillo Salcedo concluye su razonamiento con la afirmación de que «...el Derecho internacional privado ya no puede quedar reducido e identificado con el conflicto de leyes»106. La alteración o ampliación metodológicas deben resultar irrelevantes frente a la inalteración del objeto material del Derecho internacional privado, es decir, la regulación de las situaciones y relaciones caracterizadas por su internacionalidad. El cometido o la función del Derecho internacional privado siguen siendo los mismos, aun cuando servidos en la actualidad por una metodología de mayor espectro.

104 Cfr. Batiffol, en su Preface a la obra de Loussounarn y Bredin, Droit du Commerce International, cit. pág.

105 La concepción acerca del Derecho internacional privado y la definición de su objeto ha sido, y sigue siendo, cuestión permanentemente debatida por la doctrina. A favor de una concepción amplia de la citada disciplina se decantan abiertamente AGUILAR NAVARRo, en colaboración con GonzÁlez CAMpos y Aguilar BeníteZ de Lugo, Derecho Internacional Privado, vol. I, Tomo 1, 3. a edición, edit. Universidad de Madrid, 1970, pág. 28; CARRILLO SAlCEDo, Derecho Internacional Privado, Tecnos, 3. a edición, Madrid, 1983, págs. 39-129, especialmente pág. 166; PÉREZ Vera (Dir), Derecho Internacional Privado, Vol. I, Madrid, UNED, 1998, pág. 25. Por el contrario, defienden una concepción restringida FERNÁNDEZ Rozas y SÁnchez LoRenzo, Curso de Derecho Internacional Privado, Madrid, Civitas, 1991, págs. 77 a 87. Por su parte, se adhieren a una concepción intermedia CALvo Caravaca y Carrascosa González, Introducción al Derecho Internacional Privado, Granada, Comares, 1997, págs. 35 y sigs.

106 Cfr. CARrillo SAlCEDO, Derecho Internacional Privado, cit. pág. 166. 
Si se acepta la concepción amplia acerca del derecho internacional privado, tal como la han definido los autores citados, el derecho del comercio internacional podrá considerarse forma parte de aquél, de manera que el derecho internacional privado no tendría como único o esencial componente la resolución de los conflictos de leyes y de jurisdicciones, sino que, junto a tal método «clínico» de solución de conflictos, en expresión de Schmitthoff ${ }^{107}$, coexistiría este método preventivo de evitación de dichos conflictos ${ }^{108}$.

Efectivamente, en la actualidad, el Derecho del comercio internacional, entre otras funciones, parece cumplir primordialmente con aquella de evitación de conflictos. Ello viene a representar un método preventivo que puede acabar por alcanzar el mismo rango que el método clínico de las soluciones conflictuales a través del tradicional sistema conflictual. Así, acabaría por producirse una nueva concepción del derecho internacional privado, pues, de un lado, incluiría un derecho substantivo (el derecho del comercio internacional equivalente a la evitación de conflictos) y, de otro, el sistema conflictual (principalmente para la solución de los conflictos relativos al estatuto personal). Desde un punto de vista histórico, así se cierra el círculo, pues los conflictos de leyes disminuyen en la medida en que crece y se desarrolla el Derecho del comercio internacional.

107 Cfr. Schmitthoff, Conflict Avoidance in Practice and Theory, pág. 429, del citado autor, al respecto vid. asimismo, International Trade Law and Private International Law, pág. 539; de la idea se hacen eco, en la doctrina española, GoNDRA RoMERO, art. cit. pág. 16 e ILLESCAS ORTIZ, art. cit. págs. 55 y sigs.

108 La importancia concedida en la actualidad a la evitación de conflictos queda puesta de manifiesto en el simposium sobre The Preventive Law of Conflicts, en Legal Contemporary Problems, Duke University, 1956, págs. 427-605. 